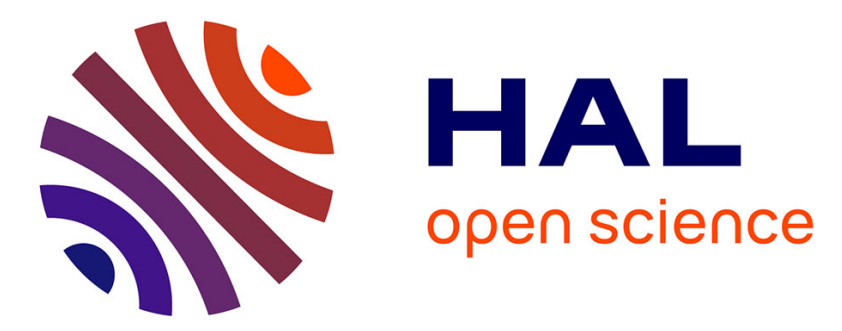

\title{
A multidating approach applied to historical slackwater flood deposits of the Gardon River, SE France
}

L. Dezileau, B. Terrier, J.F. Berger, P. Blanchemanche, A. Latapie, R. Freydier, L. Bremond, André Paquier, M. Lang, J.L. Delgado

\section{- To cite this version:}

L. Dezileau, B. Terrier, J.F. Berger, P. Blanchemanche, A. Latapie, et al.. A multidating approach applied to historical slackwater flood deposits of the Gardon River, SE France. Geomorphology, 2014, 214, p. 56 - p. 68. 10.1016/j.geomorph.2014.03.017 . hal-01059669

\section{HAL Id: hal-01059669 \\ https://hal.science/hal-01059669}

Submitted on 1 Sep 2014

HAL is a multi-disciplinary open access archive for the deposit and dissemination of scientific research documents, whether they are published or not. The documents may come from teaching and research institutions in France or abroad, or from public or private research centers.
L'archive ouverte pluridisciplinaire HAL, est destinée au dépôt et à la diffusion de documents scientifiques de niveau recherche, publiés ou non, émanant des établissements d'enseignement et de recherche français ou étrangers, des laboratoires publics ou privés. 


\section{A multidating approach applied to historical slackwater flood}

\section{deposits of the Gardon River, SE France}

L.Dezileau $^{\mathrm{a},{ }^{*}}$, B.Terrier ${ }^{\mathrm{b}}$, J. F.Berger ${ }^{\mathrm{c}}$, P.Blanchemanche ${ }^{\mathrm{d}}$, A.Latapie ${ }^{\mathrm{e}}$, R.Freydier $^{\mathrm{f}}$, L.Bremond ${ }^{\mathrm{g}}$, A.Paquier ${ }^{\mathrm{e}}$, M.Lang ${ }^{\mathrm{e}}$, J.L.Delgado ${ }^{\mathrm{h}}$ aGeosciences Montpellier, Université Montpellier 2, CNRS, UMR 5243, France bAgence de l'eau Rhône-Méditerranée et Corse, Lyon cedex, France cEnvironnement Ville et Société, Université Lumière Lyon 2, CNRS, France dArchéologie des Sociétés Méditerranéennes, CNRS, UMR 5140, France eIrstea, UR HHLY, CS 70077, Villeurbanne, France 


\section{Abstract}

26 A multidating approach was carried out on slackwater flood deposits, preserved in valley side

27 rock cave and terrace, of the Gardon River in Languedoc, southeast France. Lead-210, caesium-

28 137, and geochemical analysis of mining-contaminated slackwater flood sediments have been

29 used to reconstruct the history of these flood deposits. These age controls were combined with

30 the continuous record of Gardon flow since 1890, and the combined records were then used to

31 assign ages to slackwater deposits. The stratigraphic records of terrace GE and cave GG were

32 excellent examples to illustrate the effects of erosion/preservation in a context of a progressively

33 self-censoring, vertically accreting sequence. The sedimentary flood record of the terrace GE

34 located at $10 \mathrm{~m}$ above the channel bed is complete for years post-1958 but incomplete before.

35 During the 78-year period 1880-1958, 25 floods of a sufficient magnitude (> $1450 \mathrm{~m}^{3} / \mathrm{s}$ ) have

36 covered the terrace. Since 1958, however, the frequency of inundation of the deposits has been

37 lower:only 5 or 6 floods in 52 years have been large enough to exceed the necessary threshold

38 discharge $\left(>1700 \mathrm{~m}^{3} / \mathrm{s}\right)$. The progressive increase of threshold discharge and the reduced

39 frequency of inundation at the terrace could allow stabilisation of the vegetation cover and

40 improved protection against erosion from subsequent large magnitude flood events. The

41 sedimentary flood record seems complete for cave GG located at $15 \mathrm{~m}$ above the channel bed.

42 Here, the low frequency of events would have enabled a high degree of stabilisation of the

43 sedimentary flood record, rendering the deposits less susceptible to erosion.

44 Radiocarbon dating are used in this study and compared to the other dating techniques.Eighty

45 percent of radiocarbon dates on charcoals were considerably older than those obtained by the

46 other techniques in the terrace. On the other hand, radiocarbon dating on seeds provided better

47 results. This discrepancy between radiocarbon dates on charcoal and seeds is explained by the 
nature of the dated material (permanent wood vs. annual production and resistance to degradation

49 process). Finally, we showed in this study that although the most common dating technique used

50 in paleoflood hydrology is radiocarbon dating, usually on charcoal preserved within slackwater

51 flood sediments, this method did not permitus to define a coherent age model. Only the combined use of lead-210, caesium-137, and geochemical analysis of mining-contaminated sediments with the instrumental flood record can be applied to discriminate and date the recent slackwater deposits of the terrace GE and cave GG.

Keywords:paleoflood hydrology;floods;hydraulic modelling;lead-210;caesium-137; radiocarbon dating;historical record of mining activity

\section{1. Introduction}

Palaeoflood hydrology is the reconstruction of the magnitude and frequency of large floods using geological evidence (Baker et al., 2002). Methods and concepts of paleohydrology have been described extensively in the literature (e.g., Kochel et al., 1982; Ely and Baker, 1985; Baker, 1987; Benito and Thorndycraft, 2005). Only some of the general concepts are briefly reiterated

(i) stratigraphic and sedimentologic analyses to identify the number of flood units preserved within a particular sedimentary sequence; (ii) hydraulic modelling to calculate minimum discharge estimates from the known elevations of slackwater

66 flood sediments; (iii) dating techniques to determine the chronology of flood occurrence; and (iv) establishment of possible links between past climatic changes and the frequency/magnitude of

68 flood events. Although the main aim of palaeoflood hydrology is to lengthen the flood series

69 beyond that of the instrumental record, significant benefits can also be gained by accurately

70 dating modern slackwater flood deposits (Thorndycraft et al., 2004a,b). As these events occurred 
71 during the instrumental period, the potential to correlate the modern sedimentary flood record

72 with the data measured at gauging stations is possible. This is of particular importance in understanding the palaeoflood record preserved over centennial timescales (Benito et al., 2004). were carried out on slackwater flood deposits, preserved in valley side rock cave and terrace, of the Gardon River in Languedoc in southeast France (Fig. 1). The study sites are located near Remoulins where a gauging station has been operational over the last 130 years. This provided the potential for correlation between the instrumental and sedimentary flood records. The two largest floods of the twentieth and twenty-firstcenturies, namely the 1958 and 2002 events (with estimated discharges of $6400 \mathrm{~m}^{3} / \mathrm{s}$ and $7200 \mathrm{~m}^{3} / \mathrm{s}$, respectively, at Remoulins, compared to a mean annual flow of $33 \mathrm{~m}^{3} / \mathrm{s}$ ) occurred during the dating range of the ${ }^{137} \mathrm{Cs}$ and ${ }^{210} \mathrm{~Pb}$ methods, thereby providing the potential for comparison between these events and palaeofloods. Finally, our analysis of slackwater flood deposits illustrates important uncertainties related to stratigraphic studies of paleofloods. These uncertainties bear directly on related limitations in individual event discrimination and temporal resolution of typical slackwater paleoflood records caused by effects of erosion/preservation in a context of a progressively self-censoring vertically accreting sequence.

\section{Dating techniques}

91 Different techniques are available to date recent slackwater deposits. ${ }^{137}$ Cs dating has been used

92 for determining the chronology of modern sediment deposits. ${ }^{137} \mathrm{Cs}$ is an artificial radionuclide

93 that was first released into the atmosphere by nuclear bomb testing in the mid-1950s. The 
94 temporal patterns of ${ }^{137} \mathrm{Cs}$ input are characterized by a first peak in 1959 and a second peak at

95 1962-1964; the termination of ${ }^{137}$ Cs input occurred around mid-1980s. Some areas mayhave had 96 an additional input in 1986 after the Chernobyl incident. ${ }^{137} \mathrm{Cs}$ reached the land surface by 97 atmospheric fallout. The accumulation of ${ }^{137} \mathrm{Cs}$ in sedimentary deposits throughout the world 98 therefore began by the early to mid-1950s (e.g., Popp et al., 1988). Analysis of ${ }^{137}$ Cs has been applied to fine-grained deposits to quantify soil erosion and lake sedimentation rates (e.g., Ritchie et al., 1974; Sutherland, 1989), to date oxbow sedimentation and modern fine-grained floodplain sediments (Popp et al., 1988; Walling and He, 1997; Bonté et al., 2001; Stokes and Walling, 2003). However, ${ }^{137} \mathrm{Cs}$ is strongly adsorbed to clay particles and is transported with the 103 suspended load rather than in solution (McHenry and Ritchie, 1977). The detectable activity of ${ }^{137} \mathrm{Cs}$ is related to the clay content of the sediments (McHenry and Ritchie, 1977; Popp et al., 105 1988), which poses a potential problem when the technique is applied to alluvial deposits with 106 relatively low clay content. Studies analysing the post-bomb ${ }^{137} \mathrm{Cs}$ content in modern slackwater 107 flood deposits from the San Francisco, Paria rivers in Arizona and from the Llobregat River in 108 Spain (Ely et al., 1992; Thorndycraft et al., 2005b) have shown that the technique can also be 109 successfully applied to date fluvial sediments characterized by a mix of fine and coarser particles.

110 The ${ }^{137}$ Cs dating results from the Gardon River study reaches can be tested using the combined 111 data of palaeoflood stratigraphy, discharge estimation by hydraulic modelling and the 112 instrumental discharge record.

114 The basic methodology of ${ }^{210} \mathrm{~Pb}$ dating was established in a seminal paper by Golberg (1963).

$115{ }^{210} \mathrm{~Pb}$ precipitates from the atmosphere through ${ }^{222} \mathrm{Rn}$ decay and accumulates in surface soils, 116 glaciers, or lakes where successive layers of material are buried by later deposits. ${ }^{210} \mathrm{~Pb}$ 117 deposition on land is primarily owing to meteoric fallout; and it is adsorbed quickly and 
118 tenaciously by the surfaces of fine sediments, primarily onto clays, where, even more so than

$119{ }^{137} \mathrm{Cs}$, it is chemically immobile (Cremers et al., 1988). There it undergoes beta decay to ${ }^{210} \mathrm{Bi}$

120 with a half-life of 22.3 years. ${ }^{210} \mathrm{~Pb}$ fallout is generally found to be constant at any given location

121 over time scales relevant to ${ }^{210} \mathrm{~Pb}$ geochronology (Appleby and Oldfield, 1978, 1992; He and

122 Walling, 1996). In thesimplest model, the initial $\left({ }^{210} \mathrm{~Pb}\right)_{\mathrm{ex}}$ is assumed constant and thus $\left({ }^{210} \mathrm{~Pb}\right) \mathrm{ex}_{\mathrm{x}} \mathrm{at}$

123 any time is given by theradioactive decay law. The sedimentation rates in slackwater flood

124 deposits are clearly variable and discontinuous because of the near-instantaneous sedimentation

125 of flood deposits so that this type of model is difficult to use (He and Walling, 1996; Aalto and

126 Nittrouer, 2012). However, this technique can be successfully applied to assess whether an

127 apparent accumulation of 'fresh sediment' exists ( $<100$ years, i.e., $\sim 4$ to 5 times its decay period of

12822.3 years). ${ }^{210} \mathrm{~Pb}$ dating will be tested in the Gardon River.

130 Carbon-14 analysis is the standard technique for dating Holocene alluvial deposits. Radiocarbon

131 dating of slackwater flood sediments has an applicable age range of between ca. 300 and 55,000

132 yBP (Trumbore, 2000) and therefore cannot accurately date the sediments of flood events from

133 the most recent centuries. With atmospheric testing of nuclear weapons after $1950,{ }^{14} \mathrm{C}$ activity in

134 the troposphere rapidly increased, reaching a peak of $100 \%$ above normal in the early 1960 s

135 (Nydal and Lovseth, 1983). For post-bomb alluvial deposits, radiocarbon dating on organic

136 materials preserved within slackwater flood sediments gives a 'modern age'thatcan be useful to

137 assess whether an apparent accumulation of "fresh sediment" exists in the study area. The ${ }^{14} \mathrm{C}$ age

138 of organic materials entrained in an alluvial deposit may differ significantly from the actual age

139 of the deposit, depending on the residence time of the organics within the environment (Ely et al.,

140 1992). Thus, for flood deposits, the type of organic material available constrains the accuracy of

141 the resulting dates. In particular, detrital wood and charcoal can predate fluvial deposits by 
142 several hundred years (Atwater et al., 1990). The radiocarbon dating is not the best technique to

143 accurately date the sediments of flood events from the most recent centuries (Trumbore, 2000)

144 but was used in this study to be tested by obtaining radiocarbon dates for several types of plant

145 materials from well-dated flood deposits.

147 Ages for modern flood deposits can be correctly assigned with the use of trace metals generated

148 by mining activity. This geochemical analysis of mining-contaminated floodplain sediments has

149 been used to date floodplain sediment and slackwater flood deposits where a known historical

150 record of mining within the catchment exists (e.g., Davies and Lewin, 1974; Lewin et al., 1977;

151 Hindel et al., 1996; Knox and Daniels, 2002; Thorndycraft et al., 2004a,b). The extraction of Zn-

$152 \mathrm{~Pb}$ fromthe Gardon River basin started in 1730 (Elbaz-Poulichet et al., 2006). The number of

153 mining concessions increased significantly between 1860 and 1930 . During this period, mining

154 activity generated 400,000 tons of tailings. Between 1951 and 1963, Pennaroya and then

155 Metaleurop mining companies extensively exploited the ore generating between 2,300,000 and

$1565,000,000$ tons of tailings (30,000 tons of lead and 3500 tons of $\mathrm{Zn})$. This mining activity ceased

157 in 1993. One of the most important mines on the Gardon River basin is the Carnoules mine,

158 which has generated a total of $1,500,000$ tons of wastes. The mine officially closed on 24

159 October1963. In September 1976, the tailings partially collapsed caused by a violent

160 Mediterranean thunderstorm. This was followed in October 1976 by the sudden evacuation of the

$161100,000 \mathrm{~m}^{3}$ of water initially contained in a lake that had formed in the tailing stock. The accident

162 was responsible for a major pollution of water and soil in the Gardon River basin (DREAL,

163 2008). This paper describes a combined stratigraphic and geochemical approach to identify traces

164 of historic tin mining activity within slackwater deposits of the Gardon River. 


\section{Gardon River basin flood hydrology}

\subsection{Study area description}

The Gardon River watershed (1858 $\mathrm{km}^{2}$ at Remoulins) is located in the southeast Massif Central mountains and is $\sim 135 \mathrm{~km}$ long from its headwaters at $1699 \mathrm{~m}$ above sea level (Mount Lozere) to its confluence with the Rhône River at $6 \mathrm{~m}$ asl (Fig. 1A). The Gardon is the southern most tributary of the Rhône River. In terms of geology (Fig. 1B), the Cévennes Mountains are mainly composed of Paleozoic granite, schist, gneiss, and sandstone (Bonnifait et al., 2009). The rivers present a high degree of sinuosity in this upstream area. Farther downstream, the Gardon River crosses the Gard plains, which are based onMesozoic carbonate formations with a stratigraphical series ranging from Jurassic (west) to Cretaceous (east). Close to the Cévennes Mountains, this secondary series is interrupted by a network of NE-SW faults thatdelineate the Alès graben, a 1500-m graben filled with Tertiary sediments from the Oligocene period. The river then crosses Cretaceous limestone following deep canyons (the Gardon gorges). These limestone formations present a high degree of karstification. Downstream, the Mesozoic formations are covered with the Quaternary sediments of the Rhône River (Bonnifait et al., 2009). The high watershed of the Gardon River wasreforested during the nineteenthcenturyby calcic or acidophile medio-european beech species, whiteoak species, Castanea sativa forests, and shrublands with Juniperus communis. The limestone tablelandof Nîmes garrigue, mainly occupiedby forests of green oaks (Quercus ilex and Quercus rotundifolia), somewhiteoaks coppice, a mosaic of a substeppic grassland with annual grasses from the Thero-brachypodietea.TheMatorraltree with Juniperusphoenicea occupies therocky ledgesof the limestone tableland,whileon the rocky slopesdevelopxero-thermophilic formations with Buxus sempervirens. The limestone canyonincludesriparian vegetation composed mainly of Salix alba, Populus alba, and Fraxinus 
excelsior,with somepines(Aleppo and Pinion pines) on pedimentsand upper alluvial terraces.

\author{
Insert Fig. Inear here
}

The study sites are located in the middle reach of the Gardon River in the Cretaceous bedrock gorge, between Russan and Remoulins. Little to no changes in the shape of the canyon occurred throughout the late Holocene. The identification of flood sediment sources transported into the gorge is facilitated by the strong contrast between the granitic, basaltic, and metamorphic bedrock of the upper catchment and the carbonates of the Gardon gorge. Slackwater flood sediments have been deposited and preserved on high-standing terraces along channel margins and in many karstic caves and alcoves.

\title{
3.2. Flood hydrology and hydroclimatology
}

The Gardon River has a typically Mediterranean regime with a low mean annual discharge (33 $\mathrm{m}^{3} / \mathrm{s}$, SAGE des Gardons, 2000), extreme seasonal variations, and flood peaks around 100 times greater than the mean discharge. Mean annual rainfall in the catchment varies from 500 to 1100 mm. Nuissier et al. (2008) provided a detailed analysis of typical flash flood events in this region. Large amounts of precipitation can accumulate over several days, particularly at the end of summer and beginning of autumn, as frontal disturbances slow down and are reinforced by the relief of the Massif Central. When a Mesoscale Convective System remains quasistationary for several hours, heavy rainfall of over $200 \mathrm{~mm}$ can be recorded in less than a day and can therefore lead to devastating flash floods. 
212 A large set of hydrological data is available from the flood forecasting service (known as the

213 'Service de Prevision des Crues' or SPC30) and the local authority ('Smage des Gardons'). The 214 gauging station located at Remoulins ( $15 \mathrm{~km}$ downstream of study sites) provides stage

215 observations from 1890 onward (Fig.2). Since 1890, three major flood events have been recorded

216 with water levels $>7 \mathrm{~m}$ and estimated peak flood discharges defined from the stage-discharge

217 relationship > $5000 \mathrm{~m}^{3} / \mathrm{s}$, namely the $16-17$ October $1907\left(5300 \mathrm{~m}^{3} / \mathrm{s}\right), 4$ October $1958(6400$

$\left.218 \mathrm{~m} \mathrm{~m}^{3} / \mathrm{s}\right)$, and 8-9 September $2002\left(7000 \mathrm{~m}^{3} / \mathrm{s}\right)$ floods. This last extreme flood event claimed the

219 lives of 23 people and caused $€ 1.2$ billion worth of damage to towns and villages along the river.

220 Seven thousand houses were damaged, 100 of which were completely destroyed and 1500

221 submerged under $2 \mathrm{~m}$ of water (Huet et al., 2003).

Insert Fig. 2 near here

\subsection{Previous paleoflood studies of the Gardon River}

226 One paleoflood study of the Gardon River has been conducted just downstream of our study area

227 (Sheffer et al., 2008). The main objectives of their study were (i) to provide an accurate and 228 reliable discharge estimation of the 2002 flood at the study reach, (ii) to reconstruct a record of 229 major flood events using paleoflood hydrology, and (iii) to improve the understanding of the 230 2002flood magnitude and consider the long-term perspective of rare events and extreme flood 231 discharges provided by the paleoflood record. They concluded that according to slackwater 232 deposits found at different sites at least five extreme events occurred during the Little Ice Age. 233 Each was larger than the 2002 flood (Sheffer et al., 2008). 


\section{Methods}

\subsection{Paleoflood analysis}

239 During large floods in canyons, slackwater deposits(usually fine sands and silts) accumulate

240 relatively rapidly from suspension in sites of abrupt drop in flow velocity (Ely and Baker, 1985;

241 Kochel and Baker, 1988; Benito et al., 2003a). As a result, a layer of these deposits is formed.

242 This sediment may be preserved in protected sites, such as caves and alcoves in the canyon walls,

243 and backwater zones behind valley constrictions (Kochel et al., 1982; Ely and Baker, 1985; Baker

244 and Kochel, 1988; Enzel et al., 1994; Springer, 2002; Webb and Jarrett, 2002; Benito et al.,

245 2003b; Benito and Thorndycraft, 2005). Subsequent flood deposits may accumulate above this

246 layer by floods with stages higher than the top of the depositional sequence (Baker, 1987).

248 For this study, two depositional sequences (Fig. 3) were investigated along the Gardon River in a 249 high-standing, terrace-like bench of aggrading sediments (GE located at $10 \mathrm{~m}$ above the channel 250 bed, the base of the terrace is at $2 \mathrm{~m}$, the terrace is $70 \mathrm{~m}$ wide and $300 \mathrm{~m}$ long) and in a cave (GG 251 at $15 \mathrm{~m}$ above the channel bed). Sites of slackwater flood sediment deposition were identified 252 along the study reaches, and sections were cut to expose the sedimentary sequences. Individual 253 flood units were determined through a close inspection of depositional breaks and/or indicators of 254 surficial exposure (e.g., presence of a paleosol, clay layers at the top of a unit, detection of 255 erosional surfaces, bioturbation features, angular clast layers deposits in local alcoves or slope 256 material accumulation between flood events, fireplaces, and anthropogenic occupation layers 257 between flood events). 
262 Dating of sedimentary layers was carried out using ${ }^{210} \mathrm{~Pb}$ and ${ }^{137} \mathrm{Cs}$ methods on a centennial

263 timescale. Both nuclides together with $\mathrm{U}, \mathrm{Th}$, and ${ }^{226} \mathrm{Ra}$ were determined by gamma spectrometry

264 at the Géosciences Montpellier Laboratory. The 1-cm-thick sediment layers were sieved in order

265 to obtain the fraction smaller than $1 \mathrm{~mm}$. This material was then finely crushed after drying and

266 transferred into small gas-tight PETP (polyethylene terephtalate) tubes (internal height and

267 diameter of 38 and $14 \mathrm{~mm}$, respectively), and stored for more than 3 weeks to ensure equilibrium

268 between ${ }^{226} \mathrm{Ra}$ and ${ }^{222} \mathrm{Rn}$. The activities of the nuclides of interest were determined using a

269 Canberra Ge well detector and compared with the known activities of an in-house standard.

270 Activities of ${ }^{210} \mathrm{~Pb}$ were determined by integrating the area of the $46.5-\mathrm{keV}$ photo-peak. ${ }^{226} \mathrm{Ra}$

271 activities were determined from the average of values derived from the $186.2-\mathrm{keV}$ peak of ${ }^{226} \mathrm{Ra}$

272 and the peaks of its progeny in secular equilibrium with ${ }^{214} \mathrm{~Pb}(295$ and $352 \mathrm{keV})$ and ${ }^{214} \mathrm{Bi}(609$

$273 \mathrm{keV})$. In each sample, the $\left({ }^{210} \mathrm{~Pb}\right.$ unsupported $)$ excess activities were calculated by subtracting the

$274\left({ }^{226} \mathrm{Ra}\right.$ supported $)$ activity from the total $\left({ }^{210} \mathrm{~Pb}\right)$ activity. Note that, throughout this paper,

275 parentheses () denote activities. Activities of ${ }^{137} \mathrm{Cs}$ were determined by integrating the area of the

276 661-keV photo-peak. Error bars on $\left({ }^{210} \mathrm{Pbex}\right)$ and $\left({ }^{137} \mathrm{Cs}\right)$ do not exced $6 \%$.

277 The ${ }^{14} \mathrm{C}$ analyses were conducted at the Laboratoire de Mesure ${ }^{14} \mathrm{C}$ (LMC14) on the ARTEMIS

278 accelerator mass spectrometer in the CEA Institute at Saclay (Atomic Energy Commission).

279 These ${ }^{14} \mathrm{C}$ analyses were carried out with the standard procedures described by Tisnérat-Laborde

280 et al. (2001). The ${ }^{14} \mathrm{C}$ ages were converted to calendar years using the CALIB 6.1 .0 calibration

281 program (Stuiver and Reimer, 1993). A summary of the samples submitted for dating, and their

282 associated results, is presented in Table 1. All radiocarbon dates are quoted in the text as the $2 \sigma$

283 calibrated age range. 
Insert Table 1 near here

288 Before analysis, sediment samples were groundin an agate mortar and digested in a Teflon beaker on a hot plate. One hundred milligrams of sediment were digested using a three step procedure: 1/ $\mathrm{H}_{2} \mathrm{O}_{2}, 2 / \mathrm{HF}: \mathrm{HNO}_{3}: \mathrm{HCLO}_{4}$, and 3/HNO $: \mathrm{HCL}$. The $\mathrm{Al}$ and $\mathrm{Pb}$ concentrations were determined using an ICP-MS, X Series II (Thermo Fisher Scientific), equipped with a CCT (Collision Cell Technology) chamber at the Hydrosciences Montpellier Laboratory. Certified reference material

293 from LGC Standards, i.e., LGC6189 (river sediment), was used to check analytical accuracy and 294 precision. Measured concentrations agree with recommended values to within $10 \%$ (Al) and 3\% $295(\mathrm{~Pb})$. To find out if there was an enrichment of lead relative to the local baseline, an enrichment 296 factor $(\mathrm{EF})$ technique was used. The enrichment factor (EF) of lead is calculated following the 297 equation: $\mathrm{EF}_{\mathrm{Pb}}=(\mathrm{Pb} / \mathrm{Al})_{\text {sample }} /(\mathrm{Pb} / \mathrm{Al})_{\text {Average Local Background }}$.

$298 \mathrm{The}(\mathrm{Pb} / \mathrm{Fe})_{\text {sample }}$ is the ratio of $\mathrm{Pb}$ and $\mathrm{Fe}$ concentration of the sample and $(\mathrm{Pb} / \mathrm{Fe})_{\text {Average Local }}$ 299 background is the ratio of $\mathrm{Pb}$ and $\mathrm{Fe}$ concentration of a background. The background concentrations 300 of $\mathrm{Pb}$ were taken from the base of the terrace (i.e., pre-industrial period concentrations). 301 Grainsize analysis was conducted on contiguous $1 \mathrm{~cm}$ samples using a Beckman-Coulter 302 LS13320 laser diffraction particlesize analyser at the Géosciences Montpellier Laboratory. Grain 303 size distribution measurements were made on the $<1 \mathrm{~mm}$ sediment fraction. 
307 A one-dimensional (1D) hydraulic model of the Gorges was built using RubarBE, a numerical

308 model that solves the shallow water equations and uses an explicit second-order Godunov-type 309 scheme (El kadi Abderrezzak and Paquier, 2009). The modelled reach is $~ 31.5 \mathrm{~km}$ long and

310 extends from Russan, located at the entrance of the Gorges, to downstream of the Remoulins

311 gauging station, located at the exit of the Gorges. Topographic data were obtained from the

312 SPC30 and the Smage des Gardons. In addition, two surveying campaigns were carried out in the

313 Gorges in order to obtain detailed topographic data near the paleoflood sites. During these 314 campaigns, 21 profiles were surveyed with a Leica TC 305 total station and a differential GPS 315 Leica 1200 with GPS-GLONASS receptor. In total, 95 profiles were used to construct the 316 hydraulic model. The 2002 flood hydrographs provided by the SPC30 at Russan and Remoulins 317 gauging stations revealed that the peak flows were approximately the same at both locations. In 318 order to simulate past flood events, it was therefore decided that the flow at Remoulins be used as 319 an upstream boundary condition at Russan. The downstream boundary condition has been 320 defined with the water levels available at the Remoulins gauging station.

321 A sensitivity analysis has been conducted to assess the influence of the Alzon River, a tributary 322 draining an area of $203 \mathrm{~km}^{2}$, on the water levels calculated at the paleoflood sites.

\subsubsection{Model calibration}

325 Following the 2002 flood event, a post-event analysis of debris lines and observed water levels 326 was conducted by the Smage des Gardons. The model was thus calibrated on the 21 water levels 327 available for the 2002 event and validated on the 10 water levels recorded for the 1958 event. On 328 average, the difference between the measured water levels and the results of the model is $-0.11 \mathrm{~m}$ 329 with a standard deviation of $0.69 \mathrm{~m}$ for the 2002 flood event. For the 1958 event, the average 330 difference is $-0.95 \mathrm{~m}$ with a standard deviation of $0.94 \mathrm{~m}$. Most of the debris lines surveyed are 
331 located in the vicinity of hydraulic singularities such as bridges. The flow behaviour in these

332 areas is notably difficult to reproduce in a 1D hydraulic model. Furthermore, the levels of the

333 debris lines in the vicinity of the bridge may not be representative of the highest mean water level

334 and may be the result of water surface fluctuations thatcannot be reproduced by the 1D model.

335 The results of the calibration are therefore regarded as satisfactory.

\subsubsection{Sensitivity analysis}

340 The results of the model with the varying roughness coefficient allow the determination of an

341 envelope of stage discharge relationship at the two paleoflood sites (Fig. 4B). The sensitivity

342 analysis on the flow record used as an upstream boundary condition in the model also provides an

343 envelope on the water levels and discharges at the paleosites for each flood event. Results are

344 then compared with the historical flood records available at Remoulins to identify the events that

345 may have reached or submerged the sites (Fig.4C). Envelopes at the paleoflood sites are bound

346 by the scenarios of the sensitivity analysis of $Q \pm 10 \%$ combined with the scenarios of $K s \pm 10 \%$.

347 These results can be put into perspective with the dating approach and are discussed in the 348 following paragraphs.

\section{Results}

\subsection{Stratigraphic records of flood events in terrace $G E$ and cave $G G$}

\subsubsection{Terrace GE}

353 At terrace GE, the stratigraphy consists of 20 individual slackwater flood units. Based on the 
354 results of the hydraulic model (stage-discharge curve), a flood event of intensity similar to that of

355 the 1972 event $\left(\sim 2100 \mathrm{~m}^{3} / \mathrm{s}\right.$ at Remoulins) is required for a flood event to cover the uppermost

356 flood unit of the terrace. Figure 5 presents ${ }^{210} \mathrm{~Pb}_{\mathrm{ex}}$ and ${ }^{137} \mathrm{Cs}$ activities and the enrichment factor

357 of $\mathrm{Pb}$ for this terrace. Also illustrated is the minimum discharge estimate calculated for the

358 floodwaters to cover the terrace during flood events.

359 The ${ }^{137}$ Cs activity is recorded in flood units GE17, GE18, GE19, and GE20, with maximum

360 values of 38 and $45 \mathrm{mBq} / \mathrm{g}$ in units GE17 and GE18, respectively (Fig.5). No ${ }^{137} \mathrm{Cs}$ is found in

361 the older deposits of the profile. The first post-1955 event, identified by the first trace of ${ }^{137} \mathrm{Cs}$

362 activity in the profile, is that of GE17 indicating that the fourflood deposits GE17-GE20 all post-

363 date this period. More particularly, the high ${ }^{137} \mathrm{Cs}$ activity recorded in flood units GE17 and

364 GE18 (38 and $45 \mathrm{mBq} / \mathrm{g}$ ) can be associated to the maximum atmospheric production in the mid-

365 1960s (around 1963, Fig. 5).

366 The first flood unit containing ${ }^{210} \mathrm{~Pb}_{\mathrm{ex}}$ activity is unit GE15 located at $90 \mathrm{~cm}$ depth in the

367 stratigraphic profile, with a value of $5 \mathrm{mBq} / \mathrm{g}$. The ${ }^{210} \mathrm{~Pb}$ ex activity is recorded in flood units GE15,

368 GE17, GE18, GE19, and GE20, with a maximum value of $58 \mathrm{mBq} / \mathrm{g}$ in unit GE19. There is an

369 apparent accumulation of 'fresh sediment' (< 100 years, i.e., approximately 4 to 5 times the

370 decay period of ${ }^{210} \mathrm{~Pb}$ ) in the uppermost part of the terrace GE. The ${ }^{210} \mathrm{~Pb}_{\mathrm{ex}}$ can help us to confirm

371 a number of results produced using ${ }^{137} \mathrm{Cs}$ dating technique. The high ${ }^{210} \mathrm{~Pb}_{\mathrm{ex}}$ activity recorded in

372 flood units GE19 and its exponential decrease in the other flood deposits (GE18 to G15) suggests

373 that the uppermost part of the terrace can be considered as being stratifically undisturbed. In

374 particular, the first trace of ${ }^{210} \mathrm{~Pb}_{\mathrm{ex}}$ activity in the profile is that of GE15, thereby indicating that

375 the sixflood deposits GE15-GE20 are recent and all post-date approximately the end-1910s (Fig.

376 7). 
377 The geochemistry of the profile shows that enrichment factor (EF) of $\mathrm{Pb}$, with a range of 1.0 to

378 10.5, exhibits very high variation between the base and the top of the terrace (Fig. 5). The lowest

379 EF values of $\mathrm{Pb}$ (around 1.0) occur in flood units between GE1 and GE9. The EF is higher in the 380 uppermost flood units of the terrace, around 1.9 between GE10 and GE17, 3.3 in GE18, 10.5 in

381 GE19, while it decreases in the last flood unit GE20 (3). At $155 \mathrm{~cm}$ depth, an increase in the EF of Pboccursfrom a background value of 1.0 (GE9) to a value of 1.9 (GE11). The increase production of Pbbetween 1870 and 1905 could explain these increased levels of heavy metals (Fig 5). In terms of the relative chronology, therefore, the geochemical analysis shows that the lower stratigraphic slackwater deposits units (GE1 to GE9) are probably older than 1870 . The EF of Pbis higher in the uppermost flood units of the terrace, around 3.3 in GE18 and 10.5 in GE19.

387 The first high EF of 3.3 can be linked to the strong increase of Pbproduction during the mid388 1960s (GE18) and the very high EF of 10,5 to the major pollution of the basin in 1976 (GE19, 389 Fig. 5).

391 In addition to the trace metal, ${ }^{137} \mathrm{Cs}$ and ${ }^{210} \mathrm{~Pb}_{\mathrm{ex}}$ activities as age marker horizons, extreme floods 392 during the last 50 years also produced very prominent stratigraphic horizon. These age controls 393 were combined with the continuous record of stage available from 1890 at the Remoulins 394 gauging station located $15 \mathrm{~km}$ downstream (data from SPC 30). The combined records were then 395 used to assign ages to slackwater deposits indicative of other large floods in the GE sequence 396 (Fig 5). The 1958 event, the second largest in instrumental record $\left(6400 \mathrm{~m}^{3} / \mathrm{s}\right)$, deposited a 25 $397 \mathrm{~cm}$ - thick unit of medium sands (GE16: $270 \mu \mathrm{m}$ ). The next three floods units (GE17, GE18, and 398 GE19) are well marked by the pollution of Pband ${ }^{137} \mathrm{Cs}$ and have been assigned to three lower 399 magnitude floods $\left(4000,2900\right.$, and $3000 \mathrm{~m}^{3} / \mathrm{s}$, respectively) that occurred in 1963 , 1969, and 
400 1976, respectively (Fig. 5). Thin sedimentary layers and fine sands characterize these three flood

401 units. The 2002 event, the largest in the instrumental record, deposited a $30-\mathrm{cm}$ - thick unit of

402 medium sands (GE20). From these different flood units, a positive correlation $\left(r^{2}=0.96\right)$ exists

403 between the magnitude of the flood versus the grain size/thickness of the different units. The

404 sedimentary flood record prior to 1958 at site GE seems incomplete, as indicated by the fact that

405 fewer post-pollution flood units are preserved (sevenunits since 1890) than there were flood

406 events with a discharge of sufficient magnitude to cover the sedimentary surface (Fig. 5). Based

407 on the results of the hydraulic model, about 25 flood events would have submerged terrace GE

408 between $1870\left(>1430 \mathrm{~m}^{3} / \mathrm{s}\right)$ and $1958\left(>1700 \mathrm{~m}^{3} / \mathrm{s}\right)$ for the scenario for a roughness coefficients

$409 K$ increased by $10 \%$ and input flows overestimated by $10 \%$ (Figs. 4Cand 5). Assuming that a

410 minimum depth of water is required above the site in order for the sediment to deposit in a

411 sufficiently thick layer, it is possible that events of lower magnitudes are not recorded in the

412 sedimentary record. In that case, based on the possible relationship between sediment grain size

413 and magnitude, GE15 could be associated to 1951, GE14 to 1943, GE13 to 1933, GE12 to 1915,

414 GE11 to 1907 , GE10 to 1900 , and GE9 to 1890 (Fig. 5). Erosion, errors in hydrological

415 documentary sources, and model approximation could also be at the origin of this low correlation

416 between sedimentary flood record and the continuous record of Gardon flow between 1890 and 4171958.

\subsubsection{Cave $G G$}

422 Cave GG is located at $15 \mathrm{~m}$ above the channel bed with a minimum estimated discharge of 423 approximately $4500 \mathrm{~m}^{3} / \mathrm{s}$ required for floodwaters to reach the site (Fig. 4c). Results from the 
424 hydraulic model suggest that at least threeevents have submerged GG. Cave GG contains more 425 than $1.5 \mathrm{~m}$ of slackwater flood sediments. In this article, only the upper $35 \mathrm{~cm}$ will be discussed. 426 Six depositional units were found on the first $35 \mathrm{~cm}$, four of which correspond to flood deposits 427 (Fig.6). The flood deposits consist of fine sand to silt, featuring diffused lamination, with many 428 charcoal pieces and ash lens. Median grain size (d50) is clearly affected by the presence of 429 charcoals and ash lens. The ${ }^{137}$ Cs data indicates activity in only one sample analysed in the upper 430 part of the profile (GG4 with a value of $2 \mathrm{mBq} / \mathrm{g}$ ). The same pattern is observed for ${ }^{210} \mathrm{~Pb}_{\mathrm{ex}}$ 431 activity (Fig. 6). 210Pb activity is recorded in the flood unit GG4 (14mBq/g), with no activity in 432 the older deposits. The presence of ${ }^{137} \mathrm{Cs}$ activity and ${ }^{210} \mathrm{~Pb}$ ex activity in this unit means that the 433 age of GG4 post-date 1955 (Fig. 6). At $15 \mathrm{~cm}$ depth, a slight increase in the EF of lead occurs 434 (from a background value of 1 to a value of 1.4). The increase production of lead between 1870 435 and 1905 could explain thisincreased level of heavy metals occurring in the slackwater deposit 436 GG2 (Fig 6). The EF of lead is higher in the uppermost flood units of the terrace, around 2.2 in 437 GG3 and 4.4 in GG4. The high EF of 2.2 and more in this unit means that the age of GG3 and 438 GG4 post-date the beginning of the twentieth century but cannot be associated to precise 439 ages.The combined records were then used to assign ages to slackwater deposits indicative of 440 other large floods in the GG sequence (Fig. 6). The 1907 event, the third largest in instrumental 441 record $\left(5200 \mathrm{~m}^{3} / \mathrm{s}\right)$, deposited a $5-\mathrm{cm}$ - thick unit of fine sands (GG2). The next flood unit, 442 assigned to the second largest in instrumental record $\left(1958: 6300 \mathrm{~m}^{3} / \mathrm{s}\right)$, deposited a 5-cm- thick 443 unit of fine sands (GG3). The 2002 event, that is the largest in the instrumental record, deposited 444 a 4-cm- thick unit of fine sands (GG4). The 1961 and 1976 events didnot reach the cave and may 445 explain why the EF of Pbis not higher than 4.4. 


\subsection{Radiocarbon dating}

450 In the fluvial terrace GE, 17 dates were obtained using conventional radiocarbon analysis on 451 wood charcoals and seeds. All of the obtained dates are plotted in Fig. 7 in yBP (corrected for 452 isotopic fractionation) and calibrated to calendar years. From this recent terrace GE, one would 453 normally expect progressively younger dates in the uppermost flood units of the terrace. For 454 radiocarbon analysis on charcoals, at the exception of the first two radiocarbon dates in GE1 (200 $455 \mathrm{yBP}$ ) and GE2 (285 yBP), radiocarbon dates are older than expected for the basal part of the 456 terrace GE but considerably older (between 520 and 6540 yBP) than those obtained by the other 457 techniques in the uppermost flood units of the terrace. Uncalibrated ${ }^{14} \mathrm{C}$ ages of seeds are often in 458 an inverted stratigraphic position. However, when these ages are calibrated at 2бtheyare 459 consistent with those obtained by the other dating techniques.

\section{Discussion}

\subsection{Dating techniques}

468 Ages for modern flood deposits have been correctly assigned with the use of ${ }^{137} \mathrm{Cs}$. The presence 469 or absence of ${ }^{137} \mathrm{Cs}$ in these flood deposits of the Gardon River is not controlled by the particle 470 size distribution. In the upper four deposits (units 17 through 20 ), ${ }^{137} \mathrm{Cs}$ was detected even in the 
471 sample with the lowest clay content $(\mathrm{F}<2 \mu \mathrm{m}: 0.03 \%)$ (Fig. 5). Moreover, the uppermost pre-bomb 472 deposit (unit 15) showed no ${ }^{137} \mathrm{Cs}$ activity. There was no leaching of ${ }^{137} \mathrm{Cs}$ into the post-bomb 473 deposits from the overlying post-bomb deposits, as no samples below unit 16 showed detectable $474{ }^{137}$ Cs. Four samples from the flood deposit G20 (2002) showed ${ }^{137}$ Cs activity, although 475 atmospheric ${ }^{137} \mathrm{Cs}$ fallout is negligible during this period. The presence of ${ }^{137} \mathrm{Cs}$ in this recent 476 flood deposit could have resulted from the erosion and redeposition of post-1950 floodplain or 477 terrace deposits. Our results are consistent with other authors (Ely et al., 1992; Thorndycraft et 478 al., 2005a,b), who found that (i) ${ }^{137} \mathrm{Cs}$ is concentrated by erosion and redeposition of fine-grained 479 sediments and (ii) significant ${ }^{137} \mathrm{Cs}$ activity in sandy sediments indicates that high clay content is 480 not necessary for this method to be effective in distinguishing pre- and post-1950 deposits.

481 The ${ }^{210} \mathrm{~Pb}_{\mathrm{ex}}$ confirms a number of results produced using the ${ }^{137} \mathrm{Cs}$ dating technique. The high $482{ }^{210} \mathrm{~Pb}_{\mathrm{ex}}$ activity recorded in flood units GE19 and its exponential decrease in the other flood 483 deposits (GE18 to G15) suggests that the uppermost part of the terrace is recent $(<100$ years, 484 i.e., 4 to 5 times its decay period of 22.3 years) and can be considered as being stratigrafically 485 undisturbed. Significant ${ }^{210} \mathrm{~Pb}_{\mathrm{ex}}$ activity in sandy sediments indicates that high clay content is also 486 not necessary for this method to be used. However, without clay-normalized absorbed ${ }^{210} \mathrm{~Pb}_{\mathrm{ex}}$ 487 activity and without using amodel of ${ }^{210} \mathrm{~Pb}$ input during floods, this approach is not sufficiently 488 accurate for dating episodic sediment accumulation on terraces (Aalto and Nittrouer, 2013).

489 Ages for modern flood deposits have been correctly assigned with the use of lead generated by 490 mining activity.The latest sediment deposit GE20 (2002) presents EF of lead similar to those of 491 1969. This latest sedimentary deposit (GE20) might reflect remobilization of ancient floodplain 492 sediments, acting as a secondary contamination source during large flood events. However, the 493 similarity of EF values in the 2002 flood deposit and in current stream sediments (E. Resongles, 
494 HSM, personal communication, 2014), rather points out limited improvement of sediment quality

495 by waste water treatment over recent years. Interestingly, the values of EF of Pbin units GG3 and

496 GG4 (1958 and 2002 events in cave GG) are the same that in the equivalent flood event in the 497 sequence GE16 and GE20 (1958 and 2002 events in terrace GE). This would suggest that each 498 flood event is characterized by an EF of $\mathrm{Pb}$. This result also means that the EF ratio of Pbis not 499 controlled by the particle size distribution. If this is confirmed in later studies, EF of Pbcould be 500 used as another proxy for dating flood deposits in this study area.

501 Eighty percent of dates on charcoal samples are much older than is reasonably expected (Fig. 7).

502 In the GE terrace, the prevailing inversion of dates, with many of these recording ages older than 503 expected, is most likely a response to remobilization of sediment. The Gardon River does not 504 transport material downslope in direct fashion from upstream source areas to our study site 505 during a single, rapid flood event, but rather in a process that comprises several episodic floods, 506 small channel migration events on the Gard plain between the Alès graben and Gardon gorges is 507 envisioned. During extreme flood events, the inundated area is considerably increased and may 508 cover a part of the old terraces. Sediment is temporarily stored until it is exposed by small 509 channel migration or erosion of old terraces, mobilized and then once again redeposited. Other 510 processes may affect the radiocarbon dating techniques on charcoals such as alteration of 511 samples, by percolation, infiltration from underlying sections (Evans, 1985; Tornqvist et al., 512 1998), or hardwater effect (a term for the old-carbon reservoir derived from dissolved carbonate 513 rocks; Saarnisto, 1988). Sediments of large flood deposits in GE and GG contain a high 514 proportion of quartz, $(>45 \%)$, illite/mica $(>45 \%)$, and relatively little carbonate or dolomite $515(<3 \%)$. These minerals present in flood deposits derive mainly from the erosion of Paleozoic 516 granite, schist, and gneiss rocks in the upper part of the Gardon drainage basin. Charcoals have 517 probably the same origin, i.e.,coming from the combustion of treesthatinitially livedin the 
518 Cévennes Mountains. Thus, consistent with the origin of the sediment, our radiocarbon dates do

519 not have a significant hardwater error, i.e., not initially affected by an oldcarbon reservoir.

520 Another possible explanation lies in the industrial past of the study area. The Gardon watershed 521 presents numerous coal mines, which were extensively exploited during the nineteenthand 522 twentiethcenturies. The sediment of terrace GE contains a high proportion of small graphite 523 particles ( $\sim 80 \%$ of the carbon material in the different flood units sieved). Therefore, it can also 524 be suggested that the binding of small particles of dead carbon on the charcoal produce an aging 525 of the ${ }^{14} \mathrm{C}$ ages. We estimated the induced aging process by adding $10 \%$ of a dead carbon on a 526 charcoal dated to 1950 . Ten percent is a relatively high value. In this case, this charcoal would 527 have an age of 1079 years AD $\left(1950-\mathrm{t}_{\text {modern } 14 \mathrm{C} \text { with } 10 \% \text { of dead carbon }}=1950-\ln (100 / 90) * 8266.6\right)$, 528 which cannot explain the results of the radiocarbon dating on charcoals. To conclude, all these 529 other processes alone may not account for the extremely wide range in age offset and chronologic 530 error; and the remobilization of sediment is probably the first process, which can affect our 531 radiocarbon dates.

532 Radiocarbon dating on seeds seems to give better results. Almost two reasons mayexplain this 533 dating difference between charcoal and seeds. Firstly, the seed is an annual product of a living 534 plant when charcoal is produced by incomplete combustion of a living or dead tree/shrub, 535 possibly very old. This effect is called 'inbuilt age' or 'old wood effect'(Gavin, 2001) because 536 woody plants maintain old tissues in their structure; branches and stems could be greatly older 537 than the date of the fire event and even more than the flood event. Thus the ${ }^{14} \mathrm{C}$ date of a charcoal 538 might be significantly older than a ${ }^{14} \mathrm{C}$ date of a seed in the same flood unit. Secondly, charcoals 539 are relatively large and decay-resistant, they are likely to remain in the vicinity of the riverbank a 540 longer time than smaller and more readily decomposed seeds (Oswald et al., 2005). At site GE, 541 the seeds probably have a local origin. The identified seeds are essentially Polycnemum, Carex, 
542 Sambucus ebulus, and Medicago, which grow presently on the riverbank. However, although

543 dating of seeds provides better results than charcoal, the accuracy of this technique is limited

544 because of the large uncertainty of the ${ }^{14} \mathrm{C}$ dates compared to discrete flood events. Only the

545 combined use of ${ }^{210} \mathrm{~Pb},{ }^{137} \mathrm{Cs}$ and geochemical analysis of mining-contaminated sediments with

546 the instrumental flood record can be applied to discriminate and date the recent slackwater

547 deposits of the terrace GE and cave GG.

\subsection{Uncertainties affecting record completeness}

550 The principal goal of a typical slackwater paleoflood investigation is to enumerate floods

551 represented in the stratigraphic record as accurately and completely as possible and to determine

552 their timing as precisely as possible (Kochel and Baker, 1988). This task is influenced by several

553 types of uncertainty, which include the effects of stratigraphic ambiguity, erosion, internal

554 stratigraphic complexity, incomplete exposure, pedogenesis, stratigraphic record self-censoring

555 (House et al., 2002), and the uncertainties for dating slackwater flood sediments. Taking into

556 account these effects have important implications for evaluating the information content of

557 regional or site-specific fluvial paleoflood data. The stratigraphic records of GE and GG are

558 excellent examples to illustrate the effects of erosion/preservation in a context of a progressively

559 self-censoring vertically accreting sequence. The sedimentary flood record between 1958 and

5602010 at site GE seems complete. Prior to 1958, this record is incomplete, as indicated by the fact

561 that fewer post-pollution flood units (sevenunits) are preserved than there were flood events with

562 a discharge of sufficient magnitude to cover the sedimentary surface (25 events approximately).

563 As suggested, the most likely cause of this incomplete record is erosion. The second largest flood

564 on record was that of 1958; however, the stratigraphy suggests that this event was not responsible

565 for the erosion of earlier deposits. The contact between units GE15 and GE16 is characterized by 
566 buried soils, and no evidence of an erosive contact is observed. It is likely, therefore, that the

567 sedimentary record reflects a change in preservation potential of the sediments as distinct from 568 the erosive capability of a particular flood. During the 78-year period 1880-1958, 25 floods of a 569 sufficient magnitude (> $1450 \mathrm{~m}^{3} / \mathrm{s}$ ) have covered the terrace. Since 1958 , however, the frequency 570 of inundation of the deposits has been lower, there have only been fiveor sixfloods in 52 years 571 large enough to exceed the necessary threshold discharge $\left(>1700 \mathrm{~m}^{3} / \mathrm{s}\right)$. The progressive increase 572 of threshold discharge and the reduced frequency of inundation at the terrace could allow 573 stabilisation of the vegetation cover and improved protection against erosion from subsequent 574 large magnitude flood events (the extreme 2002 event has not eroded the buried soils of the 1976 event). A high frequency of events would not have enabled such a high degree of stabilisation, 576 rendering the deposits more susceptible to erosion.In cave GG located $15 \mathrm{~m}$ above the channel 577 bed, the sedimentary flood record between 1907 and 2010 seems complete, as indicated by the 578 fact that there are as many post-pollution flood units (threeunits) preserved as flood events with a 579 discharge of sufficient magnitude to cover the sedimentary surface (threeevents: 1907, 1958, and 580 2002). Here, the low frequency of events would have enabled a high degree of stabilisation of the 581 sedimentary flood record, rendering the deposits less susceptible to erosion. This higher 582 stabilisation is also probably facilitated by a strong decrease of the flood current velocity in this 583 cave. To conclude, at low elevation sites, frequent flooding may erode the slackwater flood 584 sediments (e.g., the lower part of terrace GE). In contrast, deposits in high elevation caves or 585 terraces (largest floods) may have a larger preservation potential, since only extreme events are 586 able to flush away the sediments accumulated at these higher sites. These observations are not 587 new. They have been stated previously in the paleoflood literature with varying degrees of 588 emphasis (House et al., 2002; Thorndycraft et al., 2005a,b). However, our study in the Gardon 589 River illuminated several types of uncertainties and suggested several others with an excellent 
example to illustrate the effects of erosion/preservation in a context of a progressively self-

591 censoring, vertically accreting sequence.

\subsection{Relation to other paleoflood records in the region}

Sheffer et al. (2008) described a series of 10 distinct slackwater deposits in a cave $12 \mathrm{~m}$ above the river bed (cave GH) at $400 \mathrm{~m}$ downstream of the GE site. From this cave, Sheffer et al. (2008) deduced an increase of flood events during the Little Ice Age and to a cold and wet phase around 2850 years ago. This is an important result because it allowed us to highlight a link between flood events and climate variability at the regional and southern European scale. Cave GH is located at

600 an elevation below the 2002 flood water level representing low magnitude floods, and slackwater

601 deposits matched a minimum associated discharge of $2600 \mathrm{~m}^{3} / \mathrm{s}$. Cave GH contains at least 602 sevenunits deposited in the last 2000 years (Sheffer et al., 2008). Assuming a minimum discharge 603 of $2600 \mathrm{~m}^{3} / \mathrm{s}$, the upper part of this cave should record at least eight flood events during the 604 twentieth century and not only sevenduring the last 2000 years. This discrepancy could be related 605 to erosion because of the low position of the cave or to erroneous radiocarbon dates. As observed 606 in terrace GE where $80 \%$ of dates on charcoal samples are much older than is reasonably 607 expected, radiocarbon ages on charcoal samples of slackwater deposits in cave GH could also be 608 erroneous in the uppermost part of this cave. To conclude, a supplementarygeochronological 609 study of this alluvial sequence would be necessary to confirm or not these first 610 palaeohydrological results of Sheffer et al. (2008). 


\section{Conclusion}

615 Our detailed paleoflood investigation on the Gardon River has shown some strengths and

616 weaknesses of slackwater paleoflood hydrology as a technique for improving understanding of

617 the frequency of floods in bedrock channels. ${ }^{210} \mathrm{~Pb},{ }^{137} \mathrm{Cs}$, and geochemical analysis of mining-

618 contaminated sediments have been used to reconstruct the history of slackwater flood deposits.

619 This approach was combined with the continuous record of Gardon water levels since 1890 to

620 assign ages to slackwater deposits. At cave GG and fluvial terrace GE, respectively located at 15

621 and $10 \mathrm{~m}$ above the channel bed, these dating techniques have been successfully applied and

622 illustrate the potential of this multidating approach in dating recent slackwater flood deposits.

623 The sedimentary flood record was complete in cave GG but not in terrace GE. We deduced that

624 at low elevation sites, frequent flooding could erode the slackwater flood sediments (e.g., the

625 lower part of terrace GE). In contrast, deposits in high elevation caves or terraces (largest floods)

626 could have a larger preservation potential, asonly extreme events were able to flush away the

627 sediments accumulated at these higher sites.

628 Most ${ }^{14} \mathrm{C}$ dates on wood charcoal samples (80\%) in the terrace GE were much older than the age

629 reasonably expected. In the terrace, the prevailing inversion of dates, with so many of these

630 recording ages older than expected, was most likely a clear response to fluvial remobilization of

631 sediment and their organic contents.Radiocarbon dating on seeds seems to give better results and

632 could be explained by an absence of 'inbuilt age' effect and low decay-resistance compared to

633 wood charcoals. However, although the dating of seeds provides better results than wood

634 charcoal, the accuracy of this technique is limited to date flood events from the most recent

635 centuries. Only the combined use of ${ }^{210} \mathrm{~Pb},{ }^{137} \mathrm{Cs}$, and geochemical analysis of mining- 
636 contaminated sediments with the instrumental flood record can be applied to discriminate and

637 date the recent slackwater deposits of the terrace GE and cave GG.

\section{Acknowledgements}

641 This project was totally funded by the ANR commission (EXTRAFLO project). The authors wish 642 to thank Thierry Montecinos, Marie Bouchet, Stéphanie Garnero, Izabelle Avril, Cyril Soustelle, 643 Neri for their help in fieldwork; the IRSTEA team for doing bathymetric cross sections; the DDE 644 Nîmes for the historical flood data; Laurent Bouby for seeds identifications. We thank the 645 Laboratoire de Mesure ${ }^{14} \mathrm{C}$ (LMC14) ARTEMIS in the CEA Institute at Saclay (French Atomic 646 Energy Commission) for the ${ }^{14} \mathrm{C}$ analyses (EXTRAFLO project). We thank the three anonymous 647 reviewers for their constructive comments on the manuscript.

\section{References}

Aalto, R.,Nittrouer, C., 2012. 210Pb geochronology of flood events in large tropical river systems. (2012). Phil. Trans. R. Soc. A 370, 2040-2074.

Appleby, P. G., Oldfield, F., 1978. The calculation of Pb-210 dates assuming a constant rate of supply of unsupported $\mathrm{Pb}-210$ to the sediment. Catena5, 1-8.

Appleby, P., Oldfield, F., 1992. Application of lead-210 tosedimentation studies. In: Ivanovich, M., Harmon, R.S.,(Eds.),Uranium Series Disequilibrium, Applicationto Earth, Marine and Environmental Sciences. Clarendon Press, Oxford, UK, pp. 773-778.

Atwater, B.F., Trumm, D.A., Tinsley, J.D., III, Stein, R.S., Tucker, A.B., Donahue, D.J., Jull, A.J.T., Payen, L.A. 1990. Alluvial plains and earthquake recurrence at the Coalinga anticline. In Rymer, M.J., Ellsworth,W.L. (Eds.),The Coalinga, California, Earthquake of May 2, 1983. Publisher City, ST, pp. 273-297, 1487.

662 Baker, V.R., 1987. Paleoflood hydrology and extraordinary flood events. Journal of Hydrology 
96, 79-99.

Baker, V.R., Kochel, R.C., 1988. Flood sedimentation in bedrock fluvial systems. In: Baker, V.R., Kochel, R.C., Patton, P.C. (Eds.), Flood Geomorphology. Wiley, city,USA, pp. 123137.

Baker, V.R., Webb, R.H., House, P.K., 2002. The scientific and societal value of paleoflood hydrology. In: House, P.K., Webb, R.H., Baker, V.R., Levish, D.R. (Eds.), Ancient Floods, Modern Hazards: Principles and Applications of Paleoflood Hydrology. Water Science and Application Series, vol. 5, AGU, Washington, DC, pp. 127- 146.

Benito, G., Sopena, A., Sanchez, Y., Machado, M.J., Perez Gonzalez, A., 2003a. Palaeoflood record of the Tagus River (central Spain) during the late Pleistocene and Holocene. Quaternary Science Reviews 22, 1737-1756.

Benito, G., Sanchez-Moya, Y., Sopena, A., 2003b. Sedimentology of high-stage flood deposits of the Tagus River, central Spain. Sedimentary Geology 157, 107-132.

Benito, G., Lang, M., Barriendos, M., Llasat, M.C., Frances, F., Ouarda, T., Thorndycraft, V.R., Enzel, Y., Bardossy, A., Coeur, D., Bobee, B., 2004. Use of systematic, palaeoflood and historical data for the improvement of flood risk estimation. Review of scientific methods. Nat. Hazards 31, 623-643.

Benito, G., Thorndycraft, V.R., 2005. Palaeoflood hydrology and its role in applied hydrological sciences. Journal of Hydrology 313, 3-15.

Bonnifait, L., Delrieu, G., Le Lay, M., Boudevillain, B., Masson, A., Belleudy, P., Gaume E., Saulnier, G.-M., 2009. Hydrologic and hydraulic distributed modelling with radar rainfall input: reconstruction of the 8-9 September 2002 catastrophic flood event in the Gard region, France.Advances in Water Resources 32, 1077-1089.

Bonté, P., Ballais, J.L., Masson, M., Ben Kehia, H., Eyraud, C., Garry, G., Ghram, A., 2001. Datations au $137 \mathrm{Cs}, 134 \mathrm{Cs}$ et $210 \mathrm{~Pb}$ de dépôts de crues du XXe siècle. Datation, XXIe rencontres internationales d'archéologie et d'histoire d'Antibes, Ed. APDCA, 141-157.

Cremers, A., Elsen, A., De Preter, P., Maes, A. 1988. Quantitative analysis of radiocaesium retention in soils.Nature335, 247-249.

Davies, B.E., Lewin, J., 1974. Chronosequences in alluvial soils with special reference to historic lead pollution in Cardiganshire, Wales. Environ Pollut 6, 49-57.

DREAL, 2008. Internet site: http://basol.developpement-durable.gouv.fr/ 
694 El kadi Abderrezzak, K., Paquier, A., 2009. One-dimensional numerical modeling of sediment transport and bed deformation in open channels. Water Resour. Res. 45, W05404.

696

697

698

699

700

701

702

703

704

705

706

Elbaz-Poulichet, F., Bruneel, O., Casiot, C., 2006. The Carnoules mine. Generation of As-rich acid mine drainage, natural attenuation processes and solutions for passive in-situ remediation. Documentation IRD, p 1-8.

Ely, L.L., Baker, V.R., 1985. Reconstructing paleoflood hydrology with slackwater deposits Verde River, Arizona. Physical Geography 6, 103-126.

Ely, L.L., Webb, R.H., Enzel, Y., 1992. Accuracy of post-bomb 137Cs and 14C in dating fluvial deposits. Quaternary Research 38, 196-204.

Enzel, Y., Ely, L.L., Martinez, J., Vivian, R.G., 1994. Paleofloods comparable in magnitude to the catastrophic 1989 dam failure flood on the Virgin River, Utah and Arizona. Journal of Hydrology 153, 291-317.

Evans, LJ., 1985. Dating methods of Pleistocene deposits and their problems. VII. Paleosols. In:ed. Rutter, N.W. (Ed.), Dating Methods of Pleistocene Depositsand Their Problems. Repr. Ser. Geosci. Canada, Toronto, Canada,pp. 53-59.

Gavin, D.G., 2001. Estimation of inbuilt age in radiocarbon ages of soil charcoal for fire history studies. Radiocarbon43, 27-44.

Golberg E., 1963. Geochronology with 210Pb. Radioactive Dating. International Atomic EnergyAgency, Vienna, Austria, pp. 121-31.

He, Q., Walling, D.E., 1996. Interpreting particle size effects in the adsorption of ${ }^{137} \mathrm{Cs}$ and unsupported ${ }^{210} \mathrm{~Pb}$ bymineral soils and sediments. J. Environ. Radioact 30, 117-137.

Hindel, R., Schalich, J., De Vos, W., Ebbing, J., Swennen, R., Van Keer, Y., 1996. Vertical distribution of elements in overbank sediment profiles from Belgium, Germany and The Netherlands. Journal of Geochemical Exploration 56, 105-122.

House, P.K., Pearthree, P.A., Klawon, J. E., 2002. Historical Flood and Paleoflood Chronology of the Lower Verde River, Arizona: Stratigraphic Evidence and Related Uncertainties.In : House, P. K., Webb,R. H., Baker, V. R., LevishD. R., (Eds.), Ancient Floods, Modern Hazards, American Geophysical Union, Washington, D.C., pp. 267-293.

Huet, P.X., Martin, J.L., Prime, P., Foin, C., Laurain, P., Cannard, 2003. Retour d'expérience décrues de septembre 2002 dans les departments du Gard, de l'Hérault, du Vaucluse, des Bouches du Rhône, de l'Ardeche et de la Drome. Rapport de l'Inspection Générale de 
l'Environnement. Ministre de l'Ecologie et du D’Developpment Durable, République

Available

at

the

Internet

site: http://www.environnement.gouv.fr/infoprat/Publications/publi-ige.htm.

Knox, J.C., Daniels, J.M., 2002. Watershed scale and the stratigraphic record of large floods. In : House, P. K., Webb,R. H., Baker, V. R., LevishD. R., (Eds.), Ancient Floods, Modern Hazards, American Geophysical Union, Washington, D.C., pp. 237-255.

Kochel, R.C., Baker, V.R., Patton, P.C., 1982. Palaeohydrology of southwest Texas. Water Resour. Res. 18, 1165-1183.

Kochel, R.C., Baker, V.R., 1988. Paleoflood analysis using slack water deposits. In: Baker, V.R., Kochel, R.C., Patton, P.C. (Eds.), Flood Geomorphology. John Wiley and Sons, U.S.A., pp. $357-376$.

Lewin, J., Davies, B.E., Wolfenden, P.J.,1977. Interaction between channel change and historic mining sediments. In K.J. Gregory (Ed.), River channel changes, pp. 353-367.

McHenry, J.R., Ritchie, J.C., 1977. Physical and chemical parameters affecting transport of 137Cs in arid watersheds. Water Resources Research 13, 923-927.

Nuissier, O., Ducrocq, V., Ricard, D., Lebeaupin, C. , Anquetin, S. , 2008. A numerical study of three catastrophic precipitating events over southern France. I : Numerical framework and synoptic ingredients. Quart. J. Roy. Meteor. Soc.134, 111-130.

Nydal, R., Lovseth, K., 1983. Tracing bomb 14C in the atmosphere 1\%2-1980. Journal of Geophysical Research 88, 3621-3642.

Oswald, W.W., Anderson, P.M., Brown, T.A., Brubaker, L.B., Hu, F.S., Lozhkin, A.V., Tinner, W., Kaltenrieder, P., 2005. Effects of sample mass and macrofossil type on radiocarbon dating of arctic and boreal lake sediments. The Holocene 15, 758-767.

Popp, C. J., Hawley, J. W., Love, D. W., Dehn, M., 1988. Use of radiometric (Cs-137, Pb-210), geomorphic, and stratigraphic techniques to date recent oxbow sediments in the Rio Puerto Drainage. Grants Uranium Region, New Mexico. EnvironmentalGeology and Water Science 3, 253-269.

Ritchie, J.C., McHenry, J.R., Gil, A.C., 1974. Fallout 137Cs in the soils of three small watersheds. Ecology 55, 887-890.

Saarnisto, M., 1988. Time-scales and dating. In: Huntley, B., WebbIII III, T. (Eds.), Vegetation History. Handbook of vegetation science. Kluwer Academic Publishers, Dordrecht, pp. 77 


\section{2.}

SAGE des Gardons, 2000. Annexe 1 au Schéma d'Aménagement et de Gestion des Eaux des gardons, SAGE, pp 187.

Sheffer, N.A., Rico, M., Enzel, Y., Benito, G., Grodek, T., 2008. The palaeoflood record of the Gardon River, France: A comparison with the extreme 2002 flood event. Geomorphology 98, $71-83$.

Springer, G.S., 2002. Caves and their potential use in paleoflood studies. In: House, P.K., Webb, R.H., Baker, V.R., Levish, D.R. (Eds.), Ancient Floods, Modern Hazards: Principles and Applications of Paleoflood Hydrology. Water Science and Applications, AGU, pp. 329-344.

Stokes, S., Walling, D.E., 2003. Radiogenic and isotopic methods for the direct dating of fluvial sediments. In: Kondolf, M., Piegay, H. (Eds.), Tools in Fluvial Geomorphology. Wiley, Chichester, pp. 233-267.

Stuiver, M., Reimer, P.J.. 1993. Extended 14C data base and revised CALIB 3.0 14C age calibration program. Radiocarbon 35, 1, 215-30.

Sutherland, R.A., 1989. Quantification of accelerated soil erosion using the environmental tracer Caesium-137. Land Degradation and Rehabilitation 1, 199-208.

Thorndycraft, V.R., Benito, G., Rico, M., Sopeña, A., Sánchez-Moya, Y., Casas-Planes, A., 2004a. A Late Holocene Paleoflood record from slackwater flood deposits of the Llobregat River, NE Spain. Journal Geological Society of India 64 (4), 549-559.

Thorndycraft, V., Brown, A.G., Pirrie, D.,2004b. Alluvial records of Medieval and prehistoric tin mining on Dartmoor, SW England. Geoarchaeology, 19, 219-236.

Thorndycraft, V., Benito, G., Rico, M., Sopeña, A., Sánchez-Moya, Y., Casas, A., 2005a. Paleoflood hydrology of the Llobregat River, NE Spain: a 3000year record of extreme floods. Journal of Hydrology 313 (1-2), 16-31.

Thorndycraft, V.R., Benito, G., Walling, D.E., Sopena, A., Sanchez-Moya, Y., Rico, M., Casas, A., 2005b. Caesium-137 dating applied to slackwater flood deposits of the Llobregat River, N.E. Spain. Catena 59, 305-318.

Tisnérat-Laborde, N., Poupeau, J.J., Tannau, J.F., Paterne, M., 2001. Development of a semiautomated system for routine preparation of carbonate samples. Radiocarbon 43, 299 304.

Tornqvist, T.E., Van Ree, M.H.M., Van’t Veer R., Van Geel B., 1998. Improving methodology 
for high-resolution reconstruction of sealevel rise and neo-tectonics and paleoecological analysis and AMS 14C dating of basal peats. Quat. Res. 49, 72-85

Trumbore, S.E., 2000. Radiocarbon geochronology. In: Noller, J.S., Sowers, J.M., Lettis, W.R. (Eds.), Quaternary Geochronology: Methods and Applications. AGU, Washington, D.C., pp. $41-60$.

Walling, D.E., He, Q., 1997. Use of fallout 137Cs in investigations of overbank sediment deposition on river floodplains. Catena 29, 263-282.

Webb, R.H., Jarrett, R.D., 2002. One-dimensional estimation techniques for discharges of paleofloods and historical floods. In: House, P.K., Weeb, R.H., Baker, V.R., Levish, D.R. (Eds.), Ancient Floods, Modern Hazards: Principles and Applications of Paleoflood Hydrology. Water Resources Monograph, vol. 5. AGU, Washington, D.C., pp. 111-12.

\section{List of figures and table}

Fig. 1: Topography, hydography, and geological maps of the Gardon river watershed.

Fig. 2: Annual maximum gage height available at Remoulins between 1890 and 2010.

Fig. 3: (A) A map showing the study sites in the Gardon Gorges. (B) Terrace (GE) and cave (GG), sites of slackwater flood sediment archives .

Fig. 4 (A) Cross sections of the paleosites used in the model; (B) Calculated stage-discharge relationships and their envelope and (C) Historical flood series at Remoulins. 
815 Fig. 5. The proposed chronology for the terrace GE slackwater flood deposits, d50, ${ }^{137} \mathrm{Cs}$

816 activities, ${ }^{210} \mathrm{~Pb}_{\text {ex }}$ activities, EF of lead, the peak annual instantaneous discharges series at

817 Remoulins. The envelope on the range of discharges at Remoulins that may have submerged the

818 site resulting from the sensitivity analysis is shown. The individual slackwater flood units

819 deposited by a particular event are annotated.

820

821 Fig. 6. The proposed chronology for the cave GG slackwater flood deposits, d50, ${ }^{137}$ Cs acticvties,

$822{ }^{210} \mathrm{~Pb}_{\text {ex }}$ activities, the peak annual instantaneous discharges series at Remoulins. The envelope on

823 the range of discharges at Remoulins that may have submerged the site resulting from the

824 sensitivity analysis is shown. The individual slackwater flood units deposited by a particular

825 event are annotated.

826

827 Fig. 7. Stratigraphy and age model of site GE. Radiocarbon ages on wood charcoals (in blue) and 828 seeds (in red) in BP and calendar ages $(2 \sigma)$

830 Table 1. Results from radiocarbon dating. All calibrated ages were calculated within $2 \sigma$.

831 Calibration was carried out using CALIB 6.1.0. The age model integrates the minimum and the 832 maximum value of the calibrated age. 


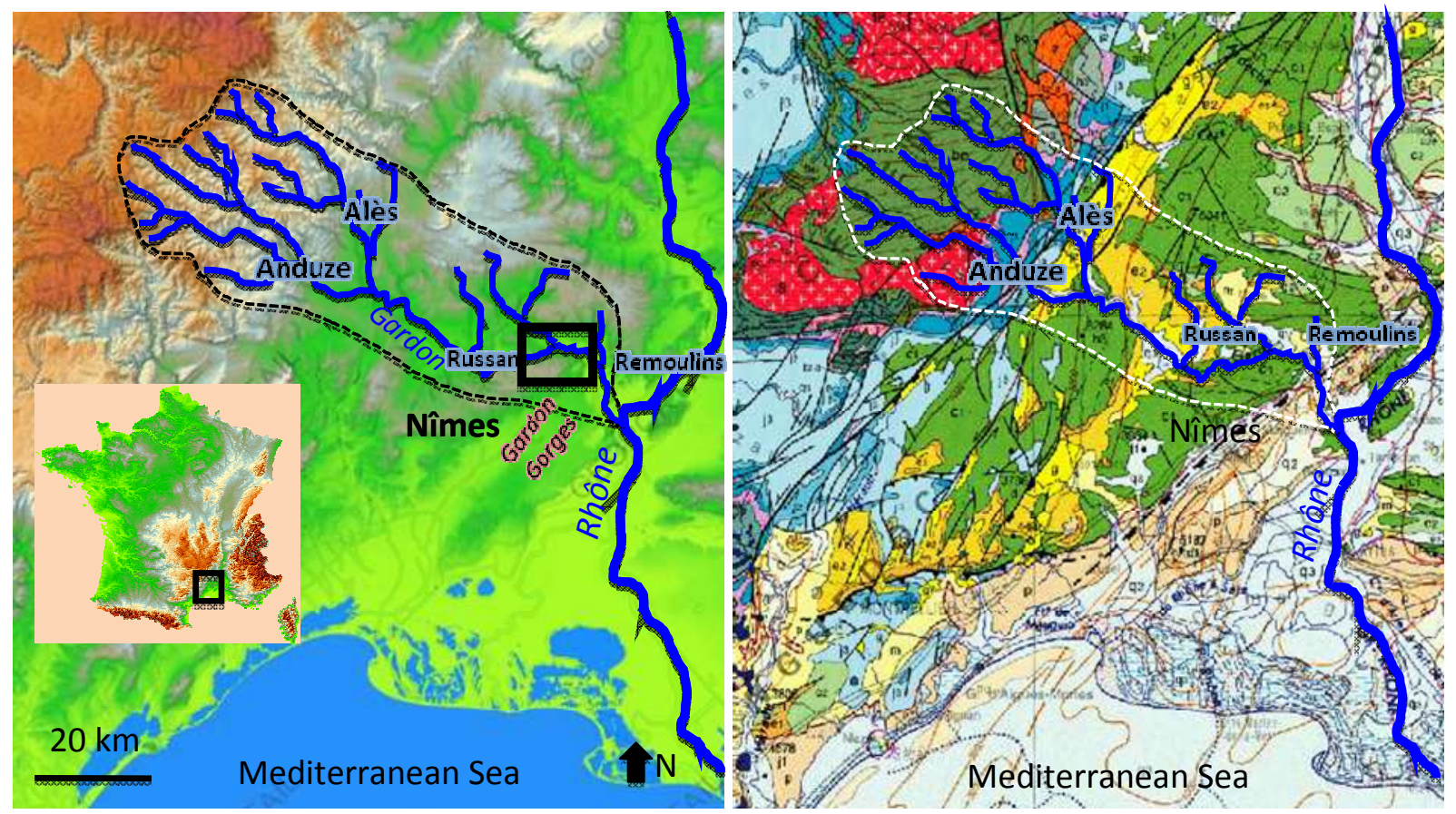

834 Fig. 1: Topography, hydography, and geological maps of the Gardon river watershed.

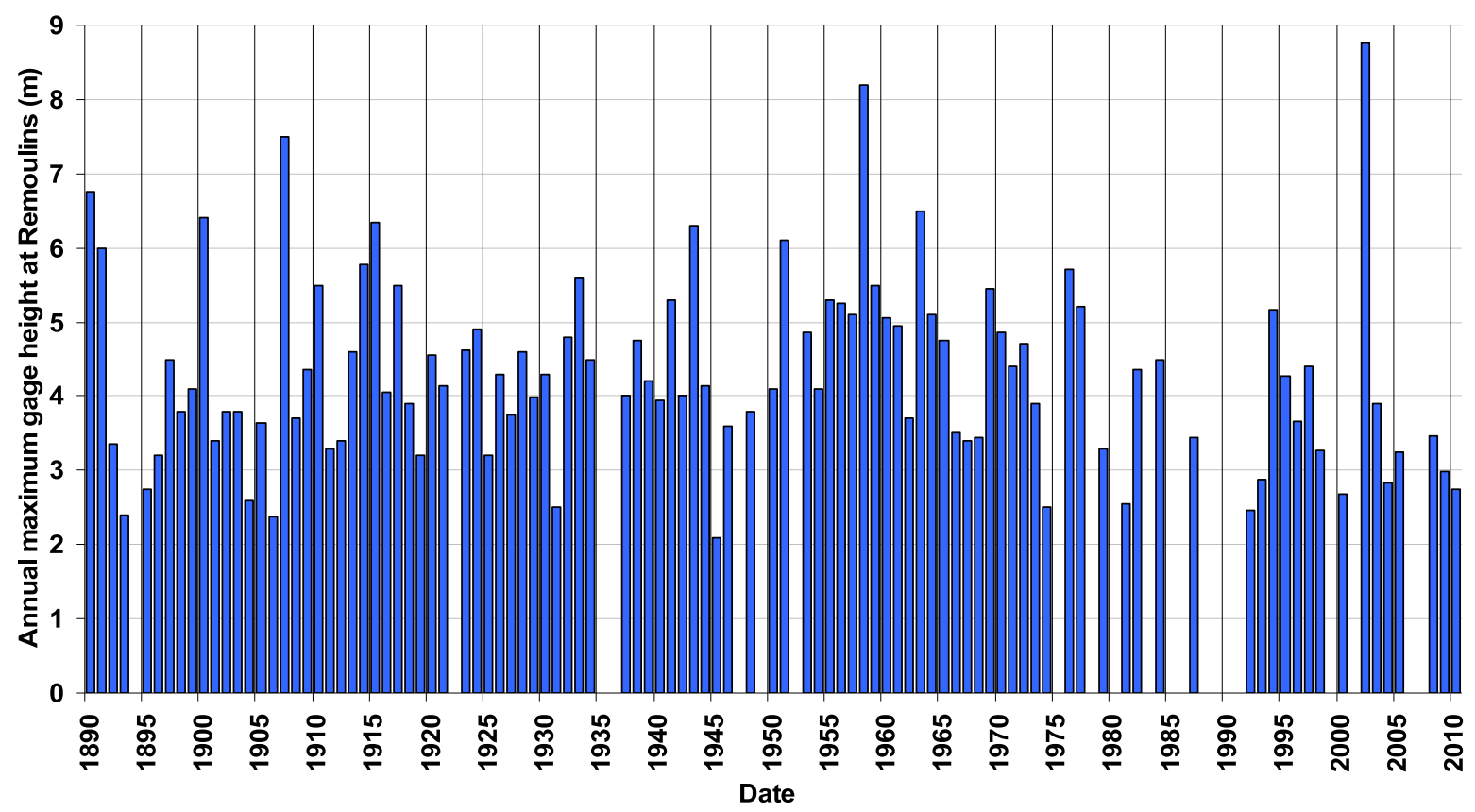

835

836

837

Fig. 2: Annual maximum gage height available at Remoulins between 1890 and 2010. 
(A)

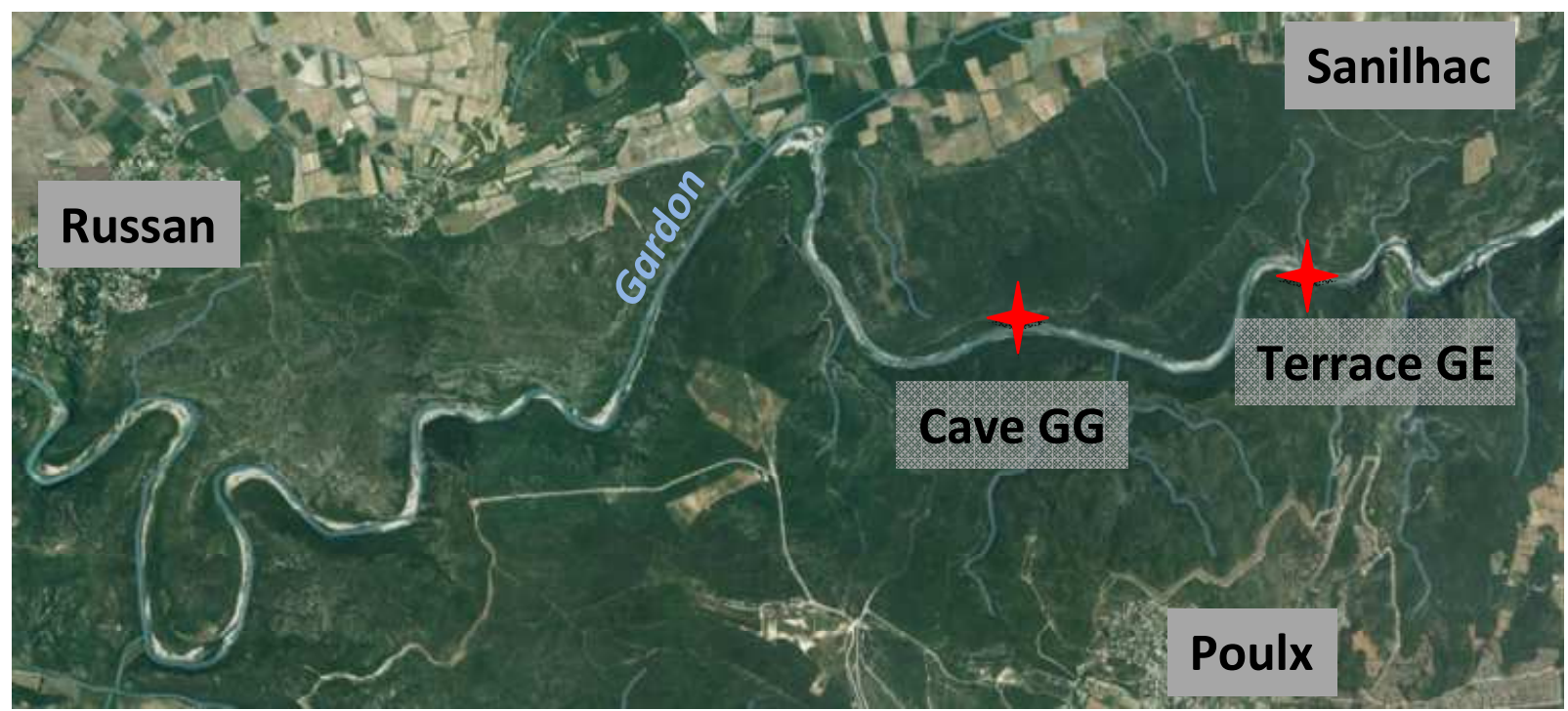

(B)
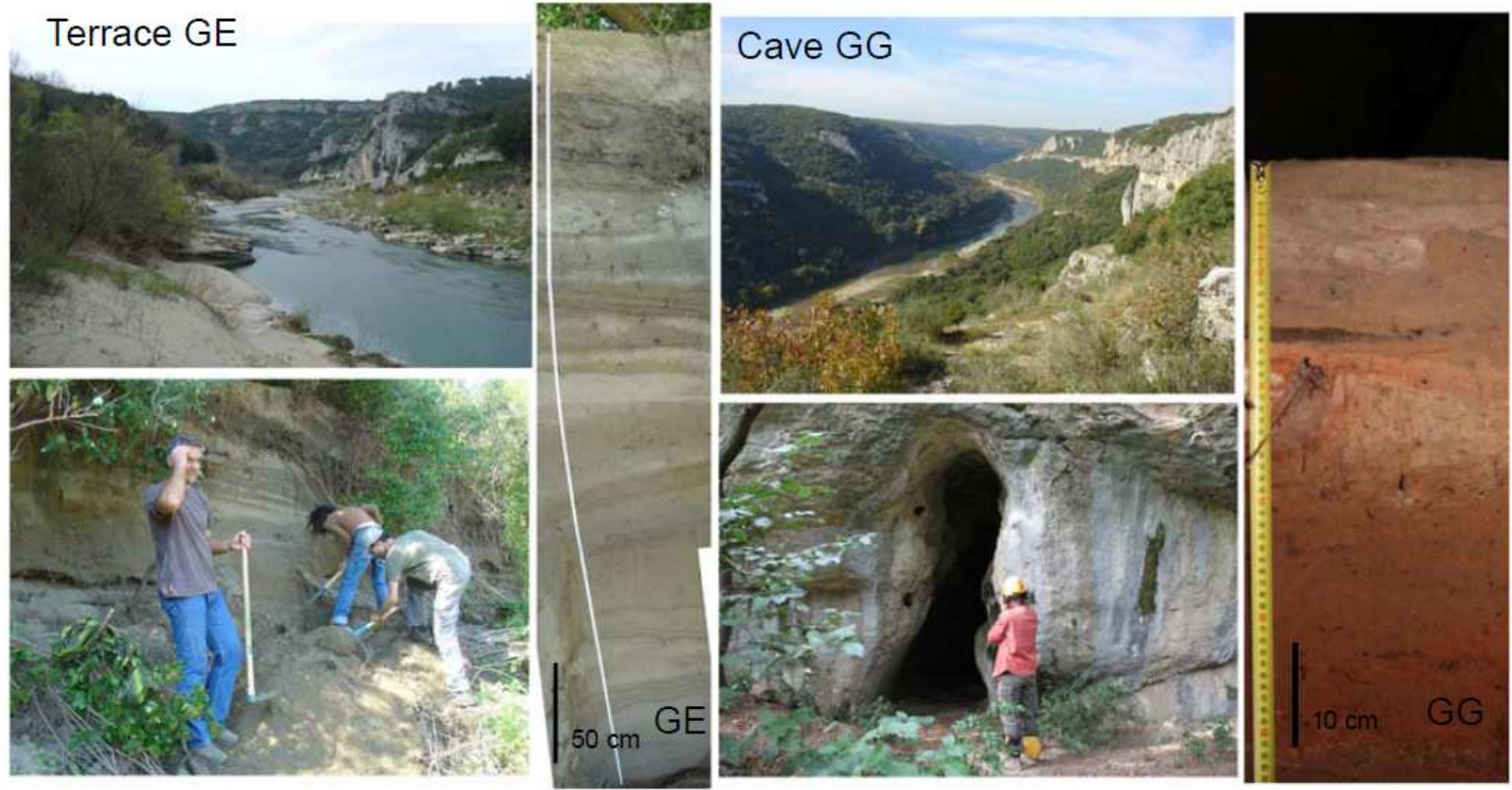

839 Fig. 3: (A) A map showing the study sites in the Gardon Gorges. (B) Terrace (GE) and cave

840 (GG), sites of slackwater flood sediment archives . 
(A)

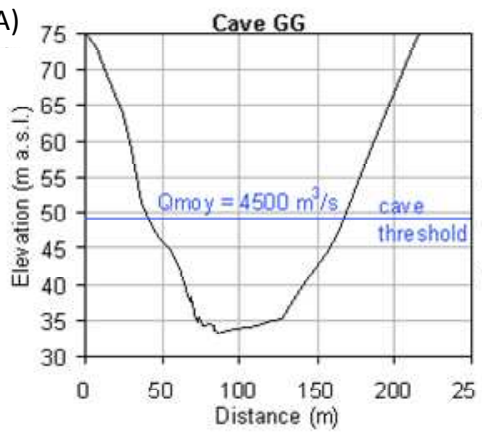

(C)

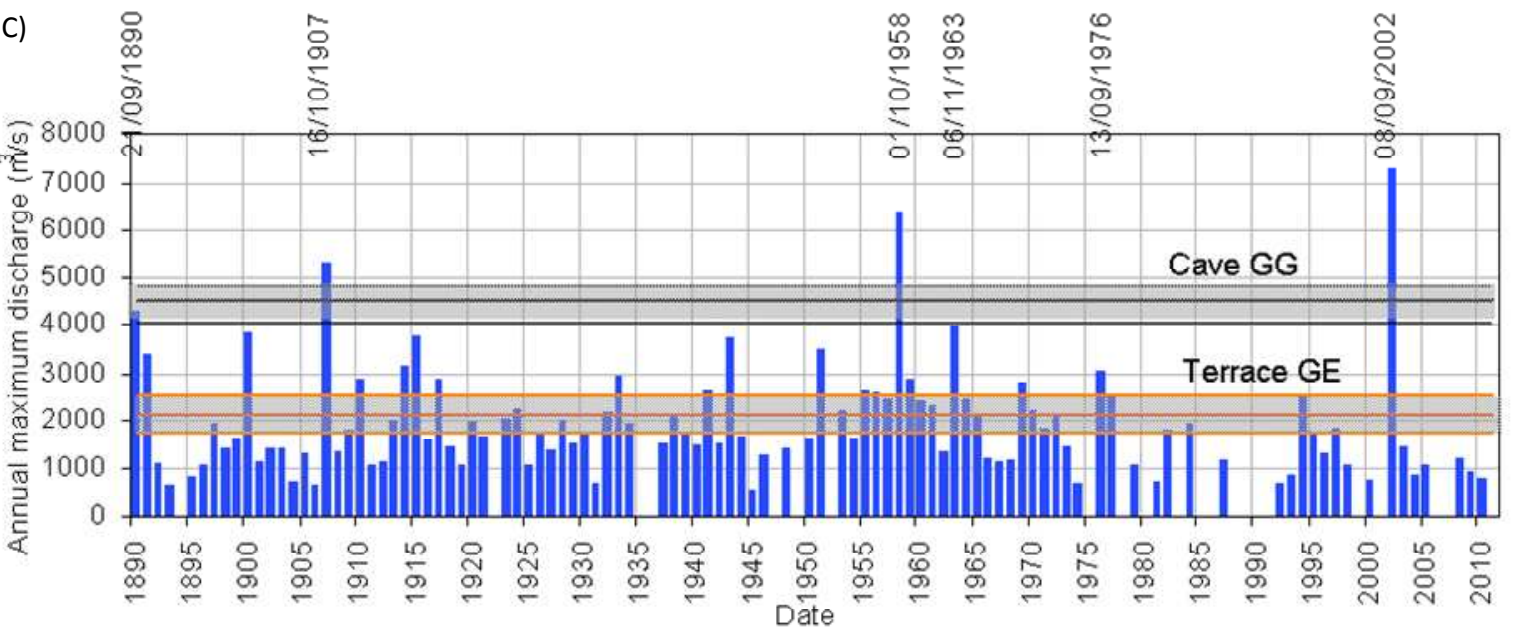

841 Fig. 4 (A) Cross sections of the paleosites used in the model; (B) Calculated stage-discharge

842 relationships and their envelope and (C) Historical flood series at Remoulins. 


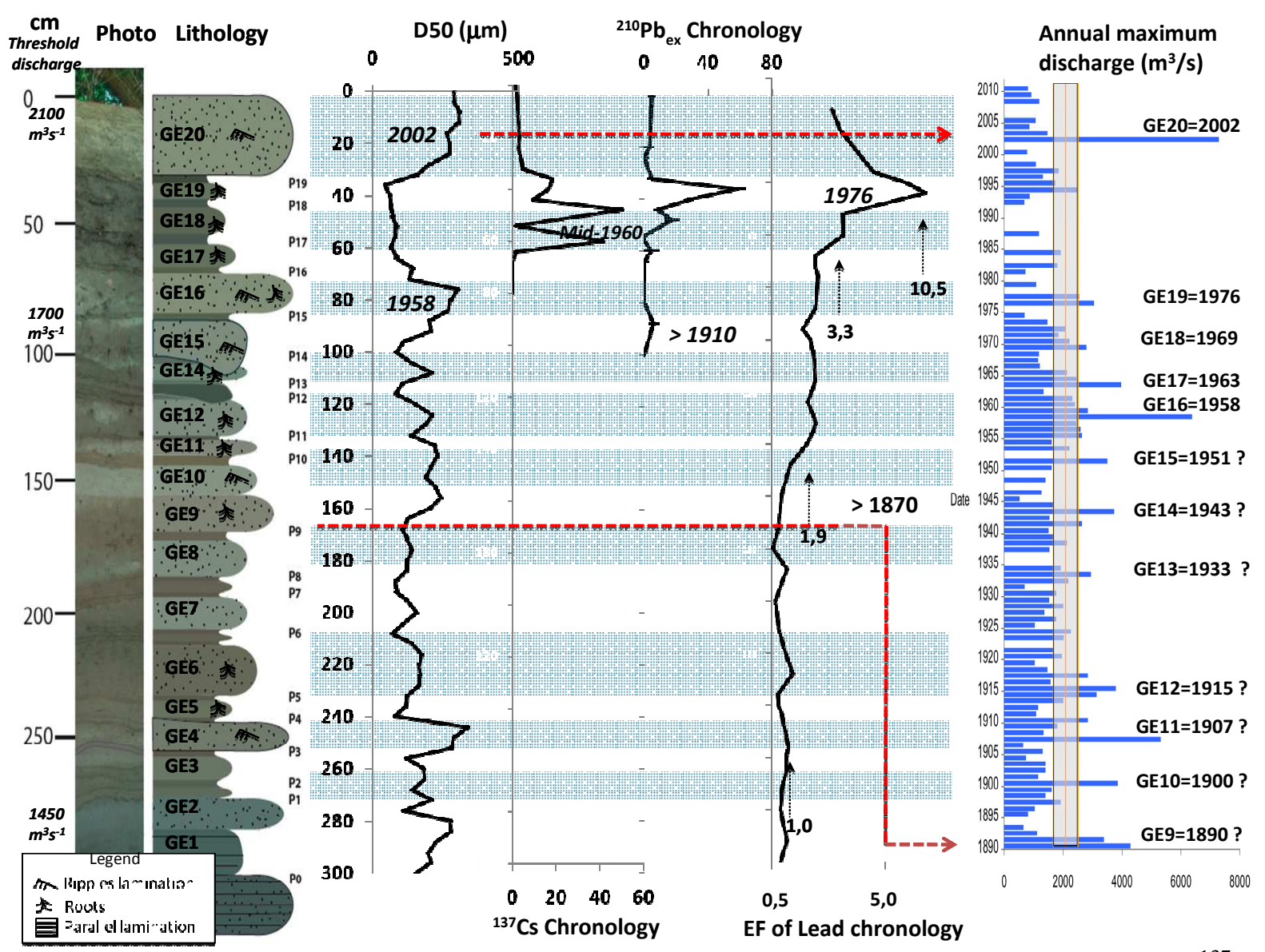

843 Fig. 5. The proposed chronology for the terrace GE slackwater flood deposits, d50, ${ }^{137} \mathrm{Cs}$

844 activities, ${ }^{210} \mathrm{~Pb}_{\text {exactivities, }}$ EF of lead, the peak annual instantaneous discharges series at

845 Remoulins. The envelope on the range of discharges at Remoulins that may have submerged the

846 site resulting from the sensitivity analysis is shown. The individual slackwater flood units

847 deposited by a particular event are annotated. 


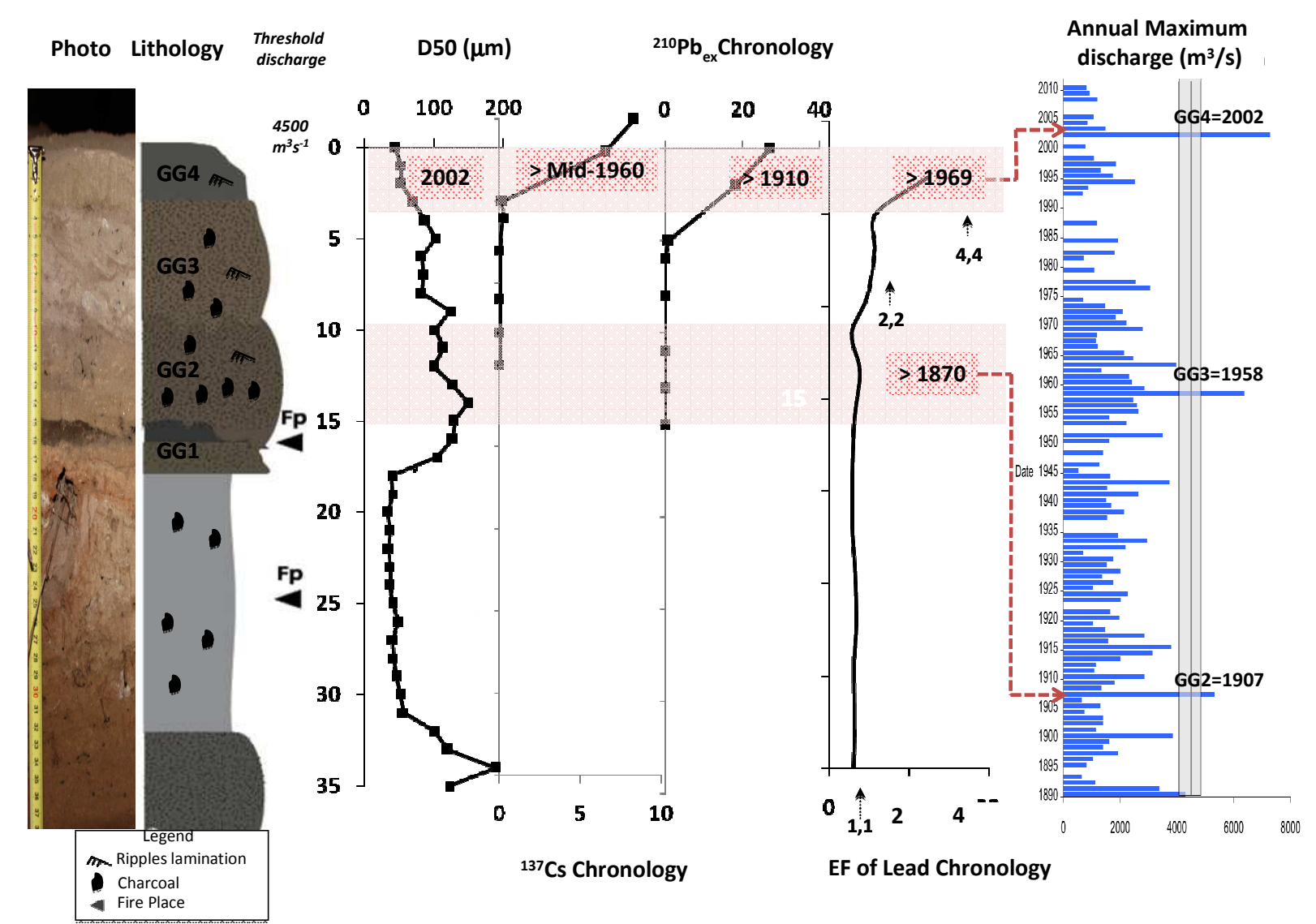

848 Fig. 6 . The proposed chronology for the cave GG slackwater flood deposits, d50, ${ }^{137}$ Cs acticvties,

$849{ }^{210} \mathrm{~Pb}_{\mathrm{ex}}$ activities, the peak annual instantaneous discharges series at Remoulins. The envelope on

850 the range of discharges at Remoulins that may have submerged the site resulting from the

851 sensitivity analysis is shown. The individual slackwater flood units deposited by a particular 852 event are annotated. 


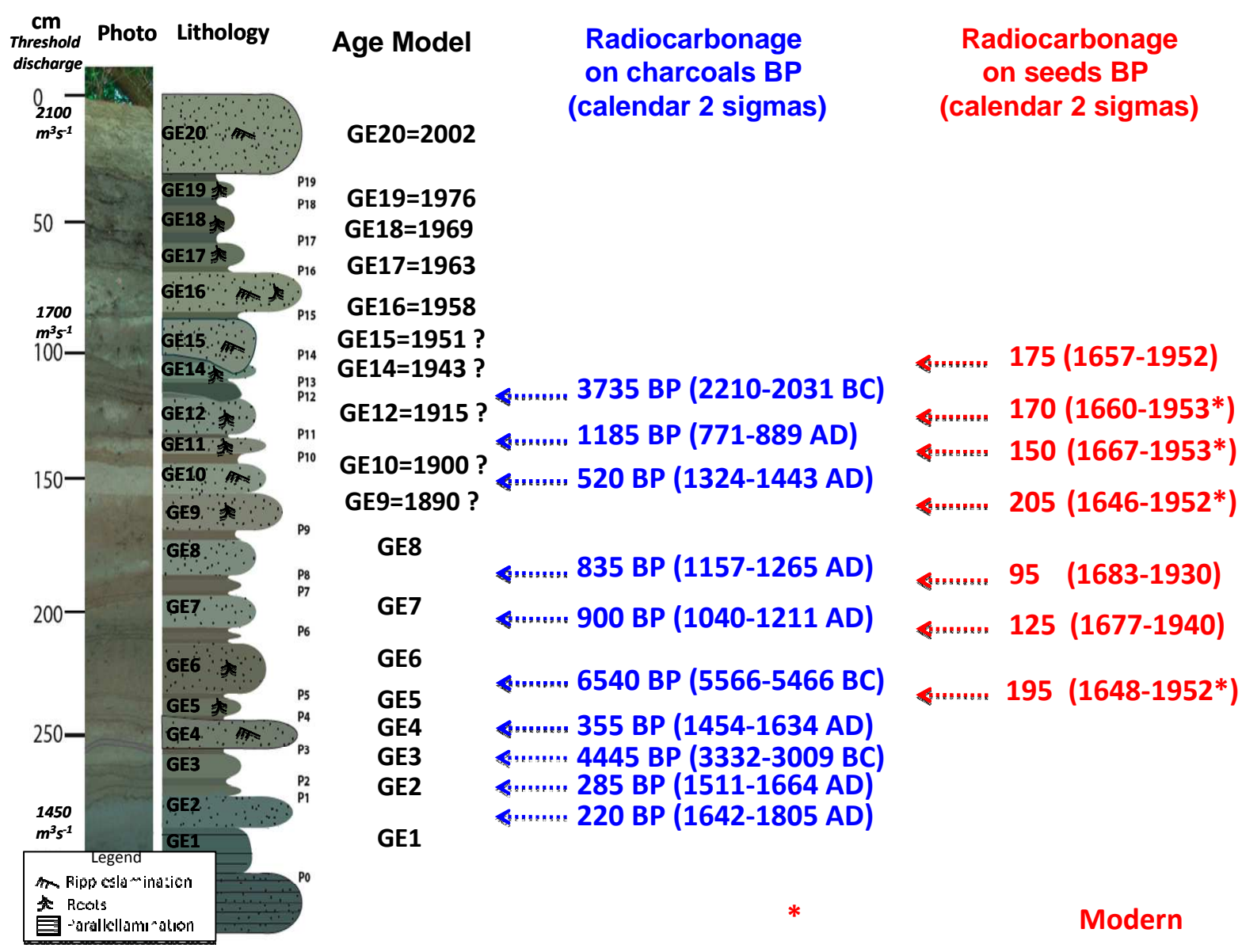

854 Fig. 7. Stratigraphy and age model of site GE. Radiocarbon ages on wood charcoals (in blue) and 855 seeds (in red) in BP and calendar ages $(2 \sigma)$ 
857 Table 1. Results from radiocarbon dating. All calibrated ages were calculated within $2 \sigma$.

858 Calibration was carried out using CALIB 6.1.0. The age model integrates the minimum and the

859 maximum value of the calibrated age.

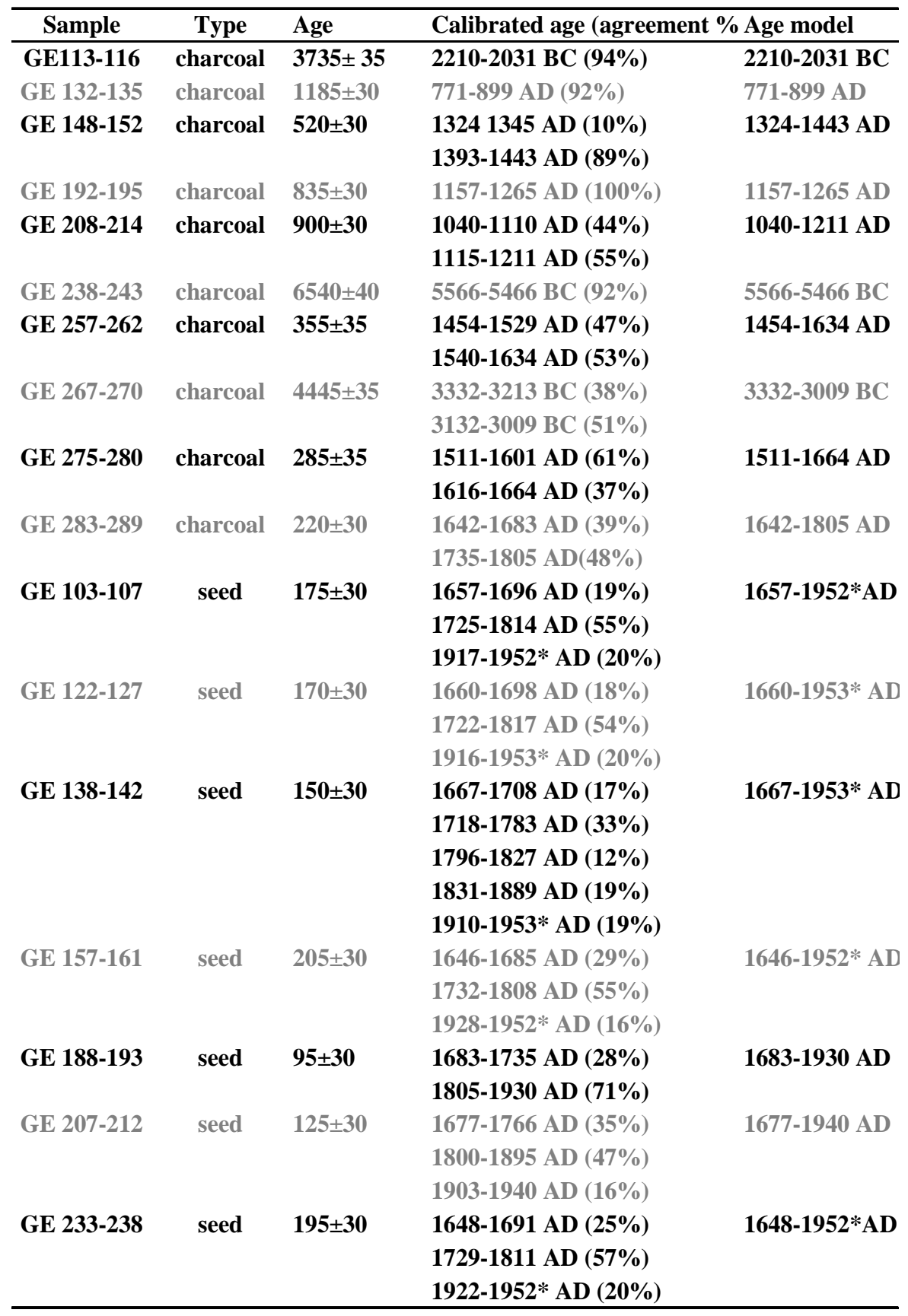

